\title{
Habitat use of adult Pacific bluefin tuna Thunnus orientalis during the spawning season in the Sea of Japan: evidence for a trade-off between thermal preference and reproductive activity
}

\author{
Ko Fujioka ${ }^{1, *}$, Kohei Sasagawa1, Tomoyuki Kuwahara ${ }^{2}$, Ethan E. Estess ${ }^{3}$, \\ Yuta Takahara ${ }^{4}$, Kazuyoshi Komeyama ${ }^{\text {, }}$ Takashi Kitagawa ${ }^{6}$, Charles J. Farwell ${ }^{3}$, \\ Seishiro Furukawa ${ }^{7}$, Junji Kinoshita ${ }^{8}$, Hiromu Fukuda ${ }^{1}$, Minoru Kato ${ }^{2}$, Akiko Aoki ${ }^{1}$, \\ Osamu Abe ${ }^{1,9}$, Seiji Ohshimo ${ }^{10}$, Nobuaki Suzuki1 \\ ${ }^{1}$ Highly Migratory Resources Division, Fisheries Stock Assessment Center, Fisheries Resources Institute, \\ Japan Fisheries Research and Education Agency, 5-7-1 Orido, Shimizu, Shizuoka 424-8633, Japan
}

Full author addresses are given in the Appendix

\begin{abstract}
To examine the habitat usage of adult Pacific bluefin tuna $(\mathrm{PBF})$, electronic tagging was conducted in the Sea of Japan during May and June of 2012-2017. Archival tags were internally implanted and pop-up satellite archival transmitting tags were deployed; data on the horizontal movements and diving behaviours of 36 individual PBF were successfully retrieved. In the summer spawning season, the tagged PBF were concentrated near Sado Island and Oki Island in the Sea of Japan, and they were distributed widely to the southwest (near Tsushima Island) or northeast (near the Tsugaru Strait) in the autumn and winter. We obtained the first long-term tracking record ( 246 d) for adult PBF, and this individual exhibited residency in a known spawning region during the spawning season in the proximity of warm-core eddy features. This fish spent most of the daytime below the thermocline between 30 and $150 \mathrm{~m}$ depths where the surface ambient temperature was $26.0 \pm 1.5^{\circ} \mathrm{C}$, but at night it ventured into the warm surface layer. Its whole-body heat transfer coefficient increased when it experienced warm waters $\left(\geq 24^{\circ} \mathrm{C}\right)$, which we suggest is a physiological response to avoid overheating. The mean peritoneal cavity temperature was only $1.8^{\circ} \mathrm{C}$ higher than the ambient temperature, compared with $6.9^{\circ} \mathrm{C}$ higher during the cooler autumn-winter period. Our hypothesis is that the warm surface temperatures found in the spawning grounds induce a physiology-reproduction trade-off in adult $\mathrm{PBF}$, which must behaviourally and physiologically ther-
\end{abstract}

${ }^{*}$ Corresponding author: fuji88@affrc.go.jp

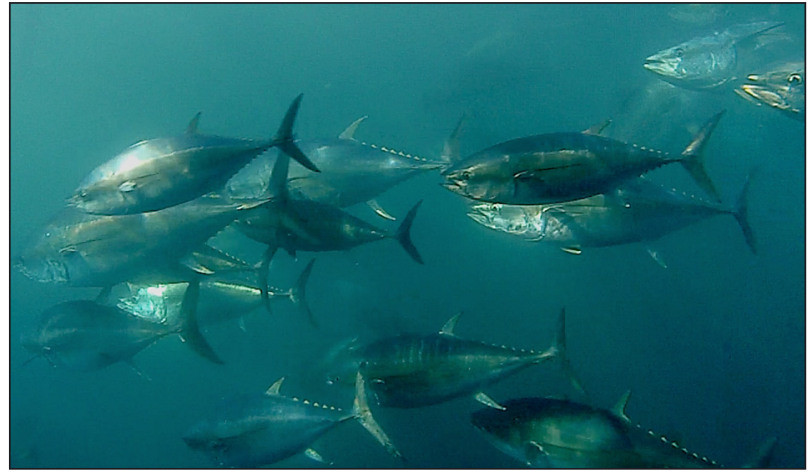

Large Pacific bluefin tuna Thunnus orientalis.

Photo: K. Fujioka

moregulate their body temperature to gain spatial and temporal access to oceanographic conditions that may promote larval survivorship and growth.

KEY WORDS: Electronic tagging - Spawning migration · Thermoregulation - Warm-core eddies · Vertical movements

\section{INTRODUCTION}

Understanding the reproductive ecology of Pacific bluefin tuna Thunnus orientalis (PBF) is essential to revealing the population dynamics of this commercially and ecologically important species. Recent

(C) The authors 2021. Open Access under Creative Commons by Attribution Licence. Use, distribution and reproduction are unrestricted. Authors and original publication must be credited. 
research on PBF gonadal development and larval distribution has advanced our understanding of the spatial and temporal patterns of spawning activity (Chen et al. 2006, Tanaka et al. 2007, Ashida et al. 2015, Okochi et al. 2016, Ohshimo et al. 2017, 2018). The Sea of Japan is one of the main spawning habitats for $\mathrm{PBF}$, in addition to the waters near the Ryukyu Archipelago and Taiwan (Ohshimo et al. 2017). Recent electronic tagging research and catch data have shown that mature PBF typically enter the Sea of Japan through the Tsugaru Strait from the Pacific Ocean and distribute southwards throughout the basin (Boustany et al. 2010, Fujioka et al. 2015, Tawa et al. 2017). Spawning likely occurs in offshore waters between Oki Island and the Noto Peninsula $\left(36-39^{\circ} \mathrm{N}, 132-137^{\circ} \mathrm{E}\right)$ (Abe et al. 2014), as evidenced by higher catch rates of $>130 \mathrm{~cm}$ fork length (FL) PBF ( $\geq 3$ yr old PBF) which exhibit maturity rates $>92 \%$ during the summer months (Okochi et al. 2016, Ohshimo et al. 2018) and by the elevated abundance of PBF larvae observed in this area between June and August (Tanaka et al. 2007, Ohshimo et al. 2017, 2018). However, the spatial and temporal patterns of the swimming behaviour of adult PBF in the spawning area have not been examined.

Previous research conducted across tuna species supports the hypothesis that spawning activity is typically restricted to periods when sea surface temperatures (SSTs) range from $24-31^{\circ} \mathrm{C}$ (Schaefer 1998, 2001). Similarly, gonadal development and larval surveys conducted in the Sea of Japan support the idea that PBF spawning occurs in waters that are $24^{\circ} \mathrm{C}$ and warmer (Kitagawa et al. 1995, Tanaka et al. 2006, Abe et al. 2014, Okochi et al. 2016, Ohshimo et al. 2017). It has been suggested that spawning activities occur under warmer SSTs as an evolutionary mechanism to increase larval survival and growth rates (Tanaka et al. 1996). Adult PBF are typically found in temperate waters between 14 and $19^{\circ} \mathrm{C}$ (Uda 1957), and the warm temperatures $\left(\geq 24^{\circ} \mathrm{C}\right)$ experienced in the spawning grounds may be less than optimal metabolically (Blank et al. 2007). PBF have relatively high metabolic rates compared with other fish species, and they exhibit regional endothermy, meaning that they are capable of maintaining body temperatures up to $12^{\circ} \mathrm{C}$ warmer than ambient water temperatures $\left(T_{\mathrm{a}}\right)$ (Kitagawa et al. 2006a, Blank et al. 2007). Furthermore, Blank et al. (2007) conducted swim tunnel respirometry experiments on juvenile PBF that demonstrated a minimum metabolic demand in water temperatures between 15 and $20^{\circ} \mathrm{C}$, and large-scale electronic tagging studies conducted in the Eastern Pacific showed that juvenile PBF typically occupy waters averaging $17^{\circ} \mathrm{C}$ (Block et al. 2011). One short-term (12 d) electronic tagging record from a PBF (230 kg) near the Ryukyu Archipelago demonstrated a peak utilization of $26.2^{\circ} \mathrm{C}$ waters (ranging from $12.0-30.8^{\circ} \mathrm{C}$ ), indicating that PBF experience exceptionally warm temperatures in their spawning habitats (Yamada et al. 2004). Unlike its other internal organs, the PBF heart operates at or near $T_{\mathrm{a}}$, and Blank (2004) indicated that prolonged exposure to temperatures near $30^{\circ} \mathrm{C}$ could lead to cardiac failure. In light of these previous studies, the warm SSTs $\left(>29^{\circ} \mathrm{C}\right.$ during the summer) of the Sea of Japan spawning grounds may be optimal for larval survivorship and growth (Ohshimo et al. 2017); however, they may present a distinct physiological challenge to adult PBF.

The goals of this study were to identify (1) the seasonal horizontal distribution of adult PBF in the Sea of Japan and (2) the seasonal vertical distribution of adult PBF and the influence of water temperature on their vertical distribution. To answer these questions, an electronic tagging experiment including 2 types of electronic tags was conducted on adult PBF $(\geq 3 \mathrm{yr}$ old) in the Sea of Japan between 2012 and 2017. Additionally, we examined (3) the relationship between PBF physiological limitations and reproductive behaviours using high-resolution (5 s sampling interval) internally implanted archival-tag data (depth, $T_{\mathrm{a}}$, peritoneal cavity temperature $\left[T_{\mathrm{b}}\right]$, and geolocation). Such descriptive information is important for understanding the thermal physiology of PBF and the spatial and temporal patterns of their spawning behaviour.

\section{MATERIALS AND METHODS}

\subsection{Electronic tagging}

To examine the habitat usage and swimming behaviour of adult PBF, an electronic tagging experiment was conducted off Sado Island in Niigata Prefecture in the Sea of Japan during May and June from 2012-2017. All PBF were caught in 2 commercially operated set nets off the northern coast of Sado Island $\left(38.23^{\circ} \mathrm{N}, 138.51^{\circ} \mathrm{E}\right.$ and $38.31^{\circ} \mathrm{N}$, $138.52^{\circ} \mathrm{E}$ ) (see Fig. 1). PBF were transferred from the set net to a tagging cradle aboard the tagging vessel using a crane-operated landing net. Once the tuna was in the tagging cradle, a fabric eye cover was placed over its eyes, and a hose was inserted into its mouth to irrigate the gills with oxygenated seawater. Straight FL measurements were obtained 
from the tip of the rostrum to the fork of the caudal fin. Archival tags (LAT 2310: $16 \mathrm{~mm}$ diameter, $76 \mathrm{~mm}$ length, $45 \mathrm{~g}$ in air; LAT 2810L: $13 \mathrm{~mm}$ diameter, $44 \mathrm{~mm}$ length, $13 \mathrm{~g}$ in air; Lotek Wireless) were implanted into the peritoneal cavity using a sterile scalpel to make a small incision $(2.0-2.5 \mathrm{~cm}$ long) through the ventral muscle wall that was subsequently closed with one suture (Ethicon suture, J365, 1, Vicryl undyed 27, CTX taper). The light level, $T_{\mathrm{a}}, T_{\mathrm{b}}$, and pressure data were archived in the tag memory every $5 \mathrm{~s}$; the predicted tag lifetime was 2-3 yr. Additionally, pop-up satellite archival transmitting (PAT) tags (MiniPAT: $38 \mathrm{~mm}$ diameter, $124 \mathrm{~mm}$ length, $60 \mathrm{~g}$ in air; Wildlife Computers) were anchored into the dorsal musculature at the base of the second dorsal fin using a titanium dart and monofilament leader coated with Kevlar and silicone heat-shrink tubing. A secondary loop attachment utilizing a titanium dart and monofilament leader was inserted posterior to the tag to improve tag retention. Time-series data ( $T_{\mathrm{a}}$ and pressure) were recorded at $10 \mathrm{~min}$ intervals. Both archivaland PAT-tagged fish received a conventional tag (Hallprint) which was placed into the musculature at the base of the second dorsal fin, crossing the pterygiophores to ensure retention. The surgical procedures generally took between 30 and $120 \mathrm{~s}$ depending on the behaviour of the fish, and the tagged fish were released directly into the open ocean from the side of the tagging vessel located opposite to the set net.

A total of 30 archival-tagged PBF (mean \pm SD: $138.7 \pm 14.4 \mathrm{~cm} \mathrm{FL}$ ) and 33 PAT-tagged PBF (141.4 $\pm 15.5 \mathrm{~cm} \mathrm{FL)} \mathrm{were} \mathrm{released} \mathrm{off} \mathrm{Sado} \mathrm{Island}$ during May-June in 2012 and 2014-2017. Of these, 8 archival-tagged PBF were recaptured (26.7\% of the total); however, 2 of these fish had shed their archival tags, and only the external conventional tags were recovered. Additionally, we were unable to successfully download data from one archival tag due to mechanical problems. Thirty-one of the PAT tags $(94.0 \%$ of the total) were released to the surface before the scheduled pop-off period $(8 \mathrm{mo})$. Three of the PAT tags were physically recovered, and their data were successfully downloaded. The percentage of successful data transmissions received via satellite ranged from $0.6-100 \%$ (mean: $87.6 \%$ ) across all individuals. We examined the horizontal movements and vertical distributions recorded by both tag types and conducted a detailed analysis of the PBF's thermal physiology using fine-scale (5 s sampling rate) archival tag data. In particular, we focused on one individual (ID252) for which we obtained long-term (246 d), high-resolution data through the spawning season and described the seasonal changes in its behaviour. See Table 1 for the release and recovery details, summarized swimming depth, and $T_{\mathrm{a}}$ and $T_{\mathrm{b}}$ data for all individuals.

\subsection{Estimation of fish geolocation}

To estimate the daily positions of archival-tagged $\mathrm{PBF}$, an integrated state-space Kalman filter statistical model was used to calculate geolocation errors, movement parameters, and the most likely tracks (Lam et al. 2008, Galuardi et al. 2010). Eight day satellite-derived composites of $0.1^{\circ}$ gridded SST data from the Pathfinder Advanced Very High Resolution Radiometer (AVHRR) were used for this analysis and are available from the NOAA Bloom-Watch 360 website (http://coastwatch.pfeg.noaa.gov/coastwatch/ CWBrowserWW360.jsp). Geolocation estimates were further refined using bathymetric corrections that modified the daily maximum swimming depth relative to the regional sea-floor depth (ETOPO1) (Teo et al. 2007a, Galuardi et al. 2010). We ran a 128 scenario model by changing the initial values of the parameters for each individual tag record, and the highest likelihood scenario was ultimately selected as the most likely track (Fujioka et al. 2018a,b). In accordance with previous studies (Nielsen et al. 2006, Schaefer et al. 2011), the model parameters quantifying the northward and eastward movement components were set at 3-7 nautical miles $\mathrm{d}^{-1}$, random errors in the longitude and latitude position estimates were set from $0.5-1.0^{\circ}$ and $1-5^{\circ}$, respectively, and the smoothing radius of the SST data parameter ranged from 30-90 nautical miles. These estimates were obtained using an unscented Kalman filter (implemented with 'ukfsst' package version 0.3 in $\mathrm{R}_{\text {; }}$ Lam et al. 2008), following the techniques described in Fujioka et al. (2018a,b).

We utilized a hidden Markov model (GPE3 software, Wildlife Computers) to estimate the daily positions of PAT-tagged PBF. The GPE3 model integrates the light level, SST, and bottom topography data (ETOPO1) to generate geolocation estimates that are accurate relative to real-time Argos-based track records (Braun et al. 2018). SST data were provided by the NOAA Office of Oceanic and Atmospheric Research Earth System Research Laboratory Physical Sciences Division (NOAA/OAR/ESRL PSD) (www. esrl.noaa.gov/psd/). We ran 5 scenarios for each individual track record, changing the swimming speed 
parameter in $0.5 \mathrm{~m} \mathrm{~s}^{-1}$ increments from $0.5-3 \mathrm{~m} \mathrm{~s}^{-1}$, and the scenario with the highest model score was selected as the most likely track. The GPE3 software estimated the location at various times each day (midnight, sunrise, noon, and sunset), but we utilized only the noontime estimates to maintain consistency with the method used to calculate the noontime location for the archival tags.

\subsection{Analyses}

The seasonal horizontal habitat preferences of PBF were investigated (summer: June-August; autumn: September-November; winter: December-February) by examining fixed kernel density outputs of the daily distribution of all tagged fish using non-parametric estimates (Kitagawa et al. 2006b, Boustany et al. 2010, Fujioka et al. 2018a). Kernel density estimates were obtained using R v.3.4.4 (The R Project for Statistical Computing: www.r-project.org/) with the MASS package (v.7.3-51.4). The search radius was set at 2 min degree $^{-1}$, and the smoothing parameters were estimated using the least-squares method. We examined the daily distribution of all tagged fish within the Sea of Japan, excluding one PAT-tagged individual (ID16P2015) that migrated out to the Pacific Ocean during the winter period (see Section 3.1 and Fig. S1 in the Supplement at www.int-res.com/ articles/suppl/m668p001_supp.pdf).

We compared the oceanographic conditions in the known PBF spawning ground in the Sea of Japan, the most likely track (without geolocation errors) of one archival-tagged PBF (ID252) with high-resolution monthly satellite-derived SST (at a depth of $50 \mathrm{~m})$ and model-derived current velocities $\left(0.1^{\circ} \times\right.$ $0.1^{\circ}$ ) from the Fisheries Research Agency (FRAROMS). A long-term (246 d) data set was successfully recorded for the tagged $\mathrm{PBF}$, during which it moved to the known spawning area in the Sea of Japan during the spawning period (see Section 3.1). We calculated the daily mean surface $T_{\mathrm{a}}$ and daily depth distributions recorded by the archival tag. The temperature-at-depth profile for each day was generated using a cubic smoothing spline and the mean swimming depth during the summer-winter period.

We proceeded to investigate patterns in PBF vertical habitat use in relation to thermocline depth across seasons within the Sea of Japan for all tagged $\mathrm{PBF}$, and specifically for the individual PBF with the long-term record (ID252). Data from each of the archival tags ( $\mathrm{n}=4$; except ID252) and PAT tags ( $\mathrm{n}=$ $18 ;>3$ d) were aggregated and analysed. Although many of our tag deployments were short-term records, we observed clear trends in vertical distribution across individuals (see Section 3.2). We analysed the mean swimming depth within $10 \mathrm{~m}$ depth bins for both day and night based on the light intensity recorded by the tags, and we calculated the mean $T_{\mathrm{a}}$ and $T_{\mathrm{b}}$ within each depth bin. The thermocline depth was defined as the $10 \mathrm{~m}$ depth bin within which $T_{\mathrm{a}}$ decreased by $0.8^{\circ} \mathrm{C}$ relative to the surface temperature (0-10 m depth) (Kara et al. 2000, Furukawa et al. 2017). Moreover, to examine the thermal preference of the PBF (ID252) in relation to the swimming depth in all seasons, we utilized a Spearman rank correlation analysis $(\mathrm{p}<0.001)$ to compare the frequency of surface swimming (shallower than $10 \mathrm{~m}$ ) and the PBF's thermal excess above the daily mean $T_{\mathrm{a}}\left(T_{\mathrm{b}}-\right.$ $T_{\mathrm{a}}$ ) calculated for each day and night period.

Finally, we explored the whole-body heat transfer coefficient $(k)$ of the archival-tagged PBF calculated during the spawning season (summer; surface $T_{\mathrm{a}} \geq$ $24^{\circ} \mathrm{C}$ ) and non-spawning season (early summer and autumn-winter; surface $T_{\mathrm{a}}<24^{\circ} \mathrm{C}$ ) to better understand how those tagged PBF (ID252, ID256, ID1723) responded to body temperatures near the theoretical upper thermal limit $\left(>30.0^{\circ} \mathrm{C}\right)$ during the spawning season. Electronic tag data were divided into hourly periods, and for each time window, we assumed that the $k$ of the PBF was in a non-steadystate condition. The rate of change in body temperature, $\frac{d T_{b}}{d t}$, can be described as follows:

$$
\frac{d T_{b}}{d t}=k\left(T_{b}-T_{a}\right)+\frac{d T_{m}}{d t}
$$

where $t$ is time and $\frac{d T_{m}}{d t}$ is the rate of change in body temperature due to metabolic heat production (Holland et al. 1992). We optimized the parameters $k$ and $\frac{d T_{m}}{d t}$ for each time window in the same manner as Teo et al. (2007a). The $T_{b}$ for each period was modelled using Eq. (1), and we used non-linear least-square methods to estimate the values of $k$ and $\frac{d T_{m}}{d t}$ that would provide the smallest sum of squares between the observed and predicted $T_{b}$ values (Optimization Toolbox, MATLAB R2018a; MathWorks).

Kitagawa et al. (2006a) reported that $\frac{d T_{m}}{d t}$ estimated by behavioural measurement data fluctuates diurnally, and its value differs approximately 1.22.1 times between day and night. Therefore, we set the initial values of the calculation parameters to those corresponding to the day and night to vary $\frac{d T_{m}}{d t}$ diurnally. First, we estimated the hourly prior $\frac{d T_{m}}{d t}$ for the whole-measurement data when $k$ was fixed at $3.6 \times 10^{-4} \mathrm{~s}^{-1}$, an arbitrary value. Then, we estimated the initial values of $\frac{d T_{m}}{d t}$ for day and night 
to determine the initial conditions for calculating the model parameters. To optimize the model, the initial conditions of $\frac{d T_{m}}{d t}$ in the day and $\frac{d T_{m}}{d t}$ in the night were used as the mean value in the day and mean value in the night, with $\frac{d T_{m}}{d t}$ as the initial condition; the hourly $k$ was estimated simultaneously. To obtain reasonable values, we set the search range of $\frac{d T_{m}}{d t}$ within $2 \sigma$ of the prior $\frac{d T_{m}}{d t}$. The diel patterns (day and night-time) of the $k$ values were statistically compared using a paired sample $t$-test.

\section{RESULTS}

\subsection{Habitat usage}

A total of 5 archival tags and 31 PAT tags were physically recovered or successfully transmitted data after being deployed on adult PBF $(142.2 \pm 15.3 \mathrm{~cm}$ FL). The duration of recorded data ranged from 7-246 d for the archival tags and 1-240 d for the PAT tags (Table 1). The errors in longitude and latitude

Table 1. Tag type (A: archival tag; P: pop-up satellite archival transmitting tag), data duration, percentage of data transmitted (received/ expected), straight fork length and weight at release/recovery, mean swimming depth, mean ambient water temperature ( $\left.T_{\mathrm{a}}\right)$, and mean peritoneal cavity temperature $\left(T_{\mathrm{b}}\right)$ for all tagged Pacific bluefin tuna

\begin{tabular}{|c|c|c|c|c|c|c|c|c|c|c|}
\hline \multirow{2}{*}{$\begin{array}{l}\text { Fish } \\
\text { no. }\end{array}$} & \multirow{2}{*}{$\begin{array}{l}\text { Tag } \\
\text { type }\end{array}$} & \multirow[t]{2}{*}{ Data duration (days) } & \multirow{2}{*}{$\begin{array}{l}\text { Percentage } \\
\text { of data re- } \\
\text { ceived (\%) }\end{array}$} & \multicolumn{2}{|c|}{ Fork length $(\mathrm{cm})$} & \multicolumn{2}{|c|}{ Body weight (kg) } & \multirow{2}{*}{$\begin{array}{l}\text { Swimming } \\
\text { depth }(\mathrm{m}, \\
\text { mean } \pm \mathrm{SD})\end{array}$} & \multirow{2}{*}{\multicolumn{2}{|c|}{$\begin{array}{cc}T_{\mathrm{a}} & T_{\mathrm{b}} \\
\left({ }^{\circ} \mathrm{C} \text {, mean }\right. & \pm \mathrm{SD})\end{array}$}} \\
\hline & & & & $\begin{array}{c}\text { At } \\
\text { release }\end{array}$ & $\begin{array}{c}\text { At } \\
\text { recovery }\end{array}$ & $\begin{array}{c}\text { At } \\
\text { release }^{a}\end{array}$ & $\begin{array}{c}\text { At } \\
\text { recovery }\end{array}$ & & & \\
\hline 260 & A & 24 May 2012 - 30 May 2012 (7) & 100 & 126.0 & 126.0 & 39.0 & 31.5 & $31.8 \pm 31.3$ & $16.2 \pm 1.4$ & $18.7 \pm 1.0$ \\
\hline 256 & A & 31 May 2012 - 13 August 2012 (75) & 100 & 136.0 & 142.5 & 48.6 & 40.4 & $15.0 \pm 25.4$ & $19.7 \pm 4.1$ & $23.5 \pm 3.5$ \\
\hline 252 & A & 31 May 2012 - 31 January 2013 (246) & 100 & 128.0 & 155.0 & 40.8 & 71.0 & $37.9 \pm 31.3$ & $20.3 \pm 3.6$ & $26.8 \pm 2.5$ \\
\hline 259 & A & 9 May 2014 - 28 June 2014 (51) & 100 & 145.5 & 146.0 & 59.1 & 44.0 & $17.7 \pm 23.4$ & $17.3 \pm 3.1$ & $20.3 \pm 2.2$ \\
\hline 1330 & A & 19 May 2014 - 4 August 2014 (78) & $0^{\mathrm{b}}$ & 122.5 & 126.0 & 36.0 & $41.0^{\mathrm{c}}$ & & & \\
\hline 506 & A & 19 May 2014 - 16 November 2015 (547) & $0^{\mathrm{d}}$ & 118.0 & & 32.3 & 73.4 & & & \\
\hline 634 & A & 18 June 2017 - 12 November 2017 (148) & $0^{\mathrm{d}}$ & 143.0 & & 56.2 & & & & \\
\hline 1723 & A & 19 June $2017-27$ August $2017(70)$ & 100 & 146.0 & & 59.7 & 50.0 & $12.2 \pm 18.1$ & $22.7 \pm 3.2$ & $24.7 \pm 1.5$ \\
\hline 15P0623 & $\mathrm{P}$ & 24 May 2016 - 7 June $2016(15)^{\mathrm{e}}$ & 5.1 & 149.5 & & 64.0 & & $71.6 \pm 52.0$ & $17.6 \pm 2.5$ & \\
\hline 15Р0624 & $\mathrm{P}$ & 2 June 2016 - 4 June $2016(3)^{\mathrm{f}}$ & 100 & 156.0 & & 72.3 & & $23.4 \pm 33.8$ & $16.6 \pm 1.6$ & \\
\hline 15P0625 & $\mathrm{P}$ & 2 June 2016 - 30 June $2016(29)^{\mathrm{g}}$ & 100 & 148.5 & & 62.7 & & $20.2 \pm 35.0$ & $19.0 \pm 3.0$ & \\
\hline 15P0627 & $\mathrm{P}$ & 7 June 2016 - 28 September $2016(113)^{\mathrm{e}}$ & 3.8 & 154.0 & & 69.7 & & & & \\
\hline 15P0628 & $\mathrm{P}$ & 2 June 2016 - 2 June $2016(1)^{\mathrm{h}}$ & 100 & 155.0 & & 71.0 & & $11.7 \pm 11.1$ & $16.7 \pm 1.2$ & \\
\hline 15Р0631 & $\mathrm{P}$ & 2 June 2016 - 2 June $2016(1)^{\mathrm{h}}$ & 100 & 156.0 & & 72.3 & & $31.5 \pm 24.4$ & $16.0 \pm 1.6$ & \\
\hline 15P0630 & $\mathrm{P}$ & 2 June 2016 - 15 June $2016(14)^{\mathrm{h}}$ & 97.6 & 154.5 & & 70.3 & & $37.1 \pm 47.7$ & $15.6 \pm 2.8$ & \\
\hline 15P0629 & $\mathrm{P}$ & 2 June $2016-8$ August $2016(68)^{g}$ & 80.7 & 147.0 & & 60.9 & & $17.8 \pm 24.3$ & $20.4 \pm 3.2$ & \\
\hline 15Р0650 & $\mathrm{P}$ & 2 June 2016 - 26 July $2016(55)^{g}$ & 97.6 & 154.5 & & 70.3 & & $20.3 \pm 29.7$ & $20.7 \pm 2.7$ & \\
\hline 15Р0639 & $\mathrm{P}$ & 2 June 2016 - 2 June $2016(1)^{\mathrm{h}}$ & 100 & 153.5 & & 69.0 & & $7.5 \pm 9.5$ & $17.0 \pm 0.8$ & \\
\hline 15P0645 & $\mathrm{P}$ & 2 June 2016 - 2 June $2016(1)^{\mathrm{h}}$ & 100 & 154.0 & & 69.7 & & $16.9 \pm 18.5$ & $15.2 \pm 1.7$ & \\
\hline 15P0647 & $\mathrm{P}$ & 2 June 2016 - 19 June $2016(18)^{\mathrm{g}}$ & 75.3 & 125.0 & & 38.1 & & $6.5 \pm 9.2$ & $19.6 \pm 1.7$ & \\
\hline 15Р0649 & $\mathrm{P}$ & 3 June 2016 - 12 June $2016(10)^{\mathrm{h}}$ & 100 & 131.5 & & 44.1 & & $17.9 \pm 12.8$ & $16.8 \pm 1.4$ & \\
\hline 15P0996 & $\mathrm{P}$ & 3 June $2016^{i}$ & 0 & 155.0 & & 71.0 & & & & \\
\hline 15Р0999 & $\mathrm{P}$ & 3 June 2016 - 3 June $2016(1)^{\mathrm{f}}$ & 100 & 132.0 & & 44.6 & & $2.3 \pm 2.2$ & $18.2 \pm 0.6$ & \\
\hline 15Р0997 & $\mathrm{P}$ & 3 June 2016 - 3 June $2016(1)^{\mathrm{h}}$ & 100 & 124.5 & & 37.7 & & $1.8 \pm 0.5$ & $18.7 \pm 0.2$ & \\
\hline 15P1000 & $\mathrm{P}$ & 3 June 2016 - 17 June $2016(15)^{\mathrm{h}}$ & 100 & 165.5 & & 85.8 & & $35.3 \pm 47.4$ & $15.5 \pm 2.1$ & \\
\hline 15P1001 & $\mathrm{P}$ & 3 June 2016 - 6 September $2016(96)^{g}$ & 75.6 & 154.5 & & 70.3 & & $15.0 \pm 24.9$ & $22.0 \pm 3.6$ & \\
\hline 15P1002 & $\mathrm{P}$ & 3 June 2016 - 8 June $2016(6)^{\mathrm{h}}$ & 100 & 113.0 & & 28.5 & & $27.0 \pm 29.1$ & $14.1 \pm 2.6$ & \\
\hline 15P1004 & $\mathrm{P}$ & 3 June 2016 - 3 June $2016(1)^{\mathrm{f}}$ & 100 & 157.0 & & 73.7 & & $10.5 \pm 7.2$ & $17.3 \pm 1.5$ & \\
\hline $15 \mathrm{P} 1005$ & $\mathrm{P}$ & 3 June 2016 - 3 June $2016(1)^{\mathrm{h}}$ & 100 & 127.0 & & 39.9 & & $2.6 \pm 1.1$ & $18.5 \pm 0.4$ & \\
\hline $16 \mathrm{P} 2018$ & $\mathrm{P}$ & 4 June $2017-7$ June $2017(4)^{\mathrm{h}}$ & 100 & 172.0 & & 95.9 & & $14.2 \pm 12.4$ & $15.6 \pm 0.8$ & \\
\hline 16P2015 & $\mathrm{P}$ & 11 June 2017 - 5 Feb $2018(240)$ & 29.2 & 144.0 & & 57.4 & & $27.8 \pm 47.4$ & $18.9 \pm 4.6$ & \\
\hline $16 \mathrm{P} 2027$ & $\mathrm{P}$ & 11 June 2017 - 21 June $2017(11)^{\mathrm{h}}$ & 75.0 & 152.0 & & 67.1 & & $98.3 \pm 40.6$ & $12.8 \pm 1.9$ & \\
\hline 16Р2023 & $\mathrm{P}$ & 11 June 2017 - 19 July $2017(39)^{\mathrm{h}}$ & 100 & 152.0 & & 67.1 & & $10.5 \pm 9.4$ & $20.5 \pm 2.2$ & \\
\hline 16P2028 & $\mathrm{P}$ & 11 June 2017 - 30 June $2017(20)^{\mathrm{h}}$ & 100 & 151.0 & & 65.8 & & $18.2 \pm 20.0$ & $18.5 \pm 2.0$ & \\
\hline 16P2026 & $\mathrm{P}$ & 11 June 2017 - 11 June $2017(1)^{g}$ & 99.6 & 127.0 & & 39.9 & & $21.2 \pm 17.6$ & $16.5 \pm 1.1$ & \\
\hline 16P2014 & $\mathrm{P}$ & 11 June 2017 - 12 June $2017(2)^{\mathrm{h}}$ & 100 & 115.0 & & 30.0 & & $14.1 \pm 12.8$ & $16.7 \pm 0.6$ & \\
\hline 16P2022 & $\mathrm{P}$ & 11 June 2017 - 27 June $2017(17)^{\mathrm{g}}$ & 75.8 & 123.0 & & 36.4 & & $13.0 \pm 11.4$ & $17.7 \pm 1.3$ & \\
\hline 16Р2021 & $\mathrm{P}$ & 11 June 2017 - 11 June $2017(1)^{g}$ & 100 & 123.0 & & 36.4 & & $22.9 \pm 18.6$ & $16.0 \pm 1.2$ & \\
\hline 16Р2017 & $\mathrm{P}$ & 11 June 2017 - 11 June $2017(1)^{\mathrm{h}}$ & 99.6 & 142.0 & & 55.1 & & $34.3 \pm 33.5$ & $14.8 \pm 1.9$ & \\
\hline 15Р0199 & $\mathrm{P}$ & 18 June 2017 - 1 July $2017(14)^{g}$ & 59.0 & 129.0 & & 41.8 & & $36.1 \pm 29.1$ & $17.6 \pm 2.5$ & \\
\hline 15P0200 & $\mathrm{P}$ & 18 June $2017^{\mathrm{i}}$ & 0 & 148.0 & & 62.1 & & & & \\
\hline
\end{tabular}


from the geolocation model were $1.38 \pm 1.07$ and 0.84 $\pm 0.68^{\circ}$, respectively, and the estimated SST error was $0.55 \pm 0.19^{\circ} \mathrm{C}$. The estimated daily locations of all tagged PBF during the summer are shown with kernel density contours in Fig. 1a. Fig. 1b,c demonstrate the variation in habit use between seasons in the Sea of Japan with latitude and longitude, respectively. All tagged PBF $(\mathrm{n}=36)$ remained within in the waters near Sado Island after release in the early summer, and some individuals moved southwest towards the Noto Peninsula $(\mathrm{n}=11)$ or northwards along the coast of Honshu ( $\mathrm{n}=11)$ (Fig. 1). In summer, tagged PBF were distributed between 2 areas: (1) offshore waters around Oki Island and (2) coastal waters between Niigata Prefecture and the Tsugaru Strait.
The first area $\left(36-39^{\circ} \mathrm{N}, 132-137^{\circ} \mathrm{E}\right)$ overlaps with the well-known spawning area for PBF in the Sea of Japan (Abe et al. 2014, Okochi et al. 2016, Ohshimo et al. 2017, 2018) and with a second area described in recent studies (Ohshimo et al. 2017, 2018). In autumn, the area with the highest occurrence of PBF shifted to either the southwestern or northeastern edge of the Sea of Japan. During the winter, some of the tagged PBF dispersed southwards towards Tsushima Island and the East China Sea $(n=1)$ or through the Tsugaru Strait to the Pacific Ocean around the Shatsky Rise $\left(30-40^{\circ} \mathrm{N}, 155-165^{\circ} \mathrm{E}\right)(\mathrm{n}=1)$ (see Fig. $\mathrm{S} 1$ for full track records of PBF ID16P2015).

We successfully recovered a long-term (246 d) record from an archival-tagged adult PBF (ID252)

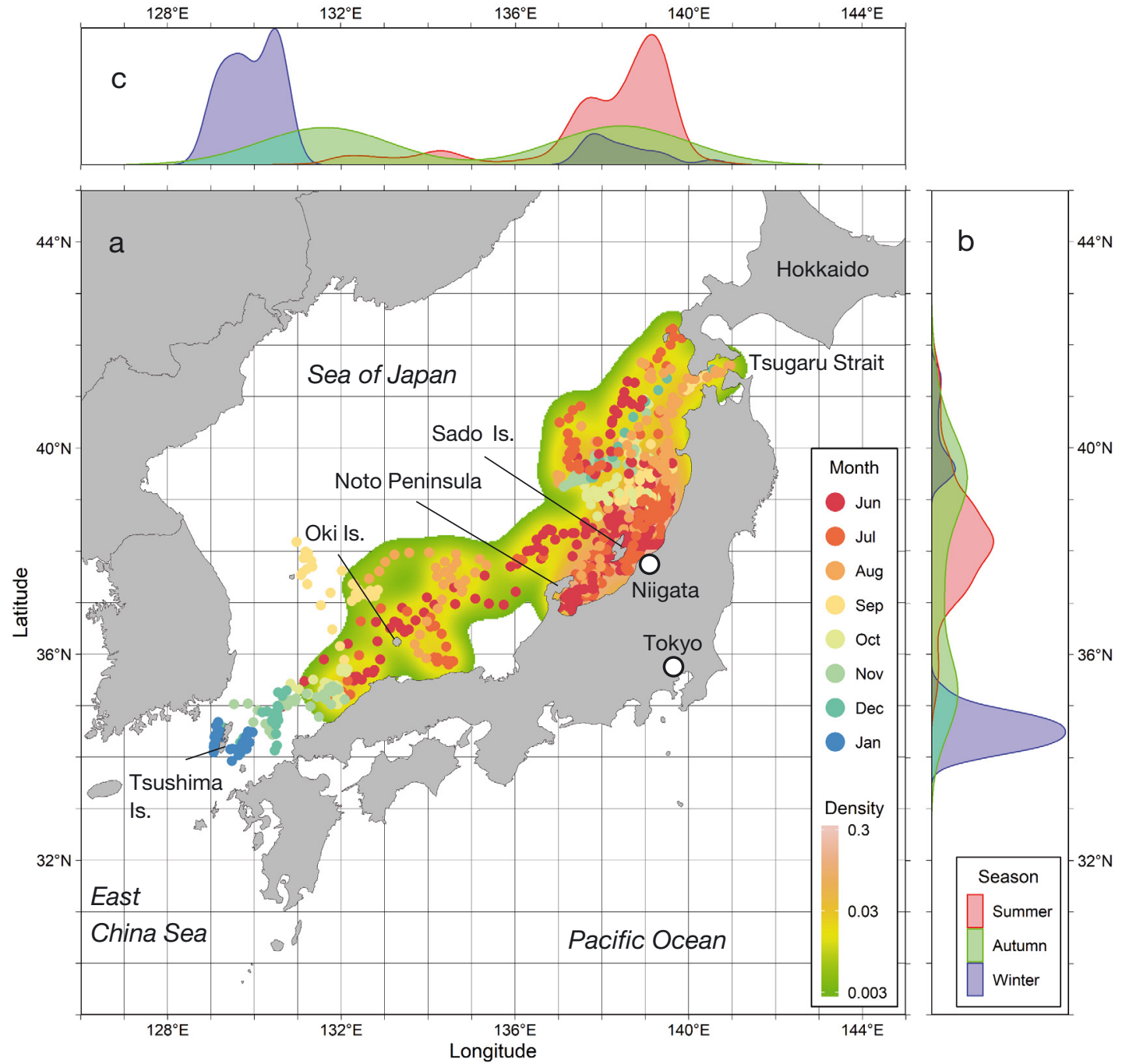

Fig. 1. (a) Estimated daily locations of all tagged Pacific bluefin tuna (PBF) based on recovered archival tags ( $\mathrm{n}=5$ ) and pop-up satellite archival transmitting (PAT) tags $(n=30)$ released between 2012 and 2017 with kernel density estimation indicating the distribution of the PBF during the summer spawning season (warmer colours indicate higher densities, see colour bar). Side plots indicate the kernel density of PBF distribution across seasons with (b) latitude and (c) longitude for all daily location estimates 
that migrated to the known spawning area in the Sea of Japan during the summer spawning season (Fig. 2a). We closely examined this individual PBF's
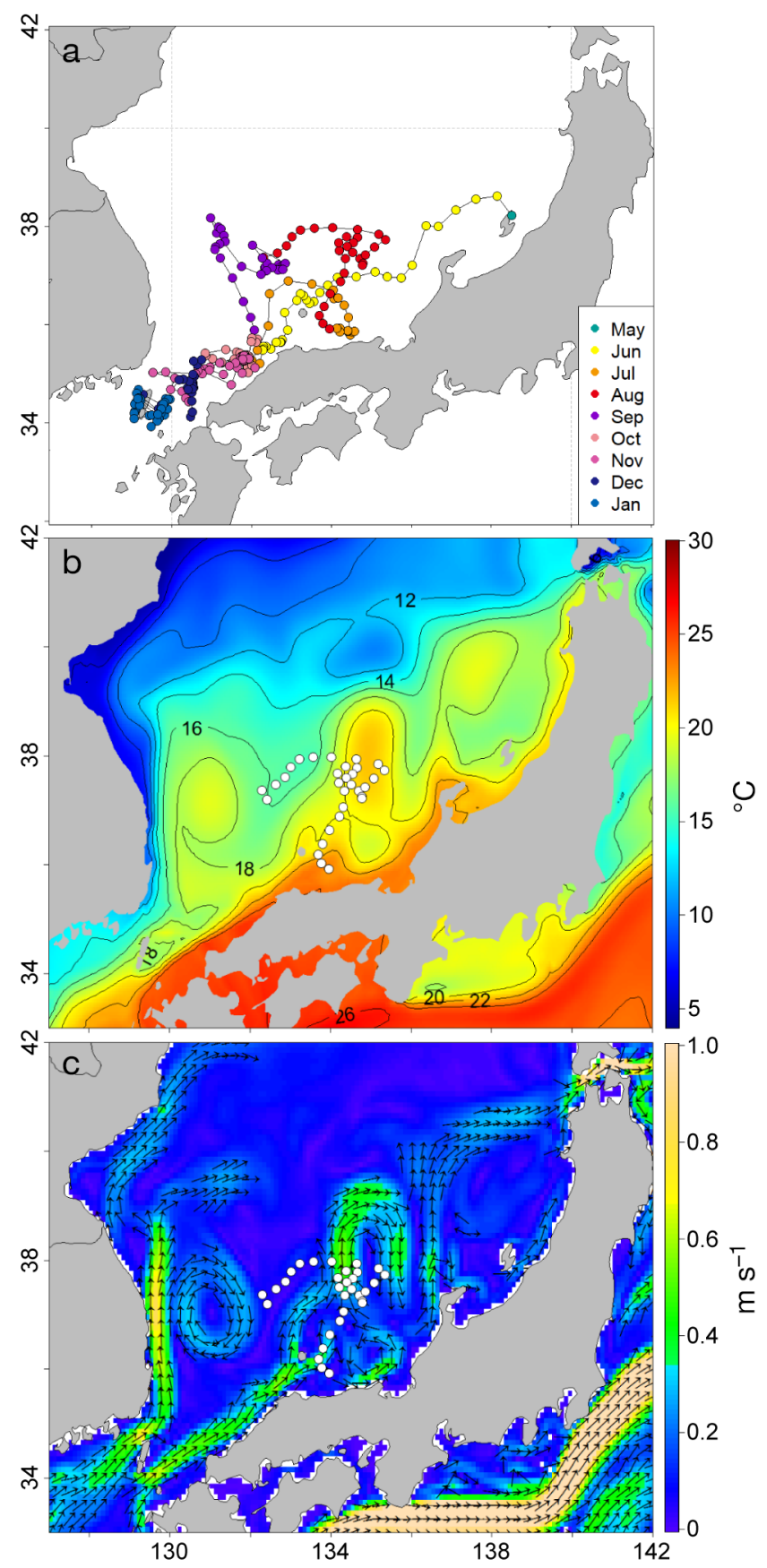

Fig. 2. (a) Long-term movements (246 d) of a tagged PBF (ID252) during the spawning season in the Sea of Japan. Daily locations of the tagged PBF during August are shown with (b) subsurface $(50 \mathrm{~m})$ temperature contours and (c) the direction and velocity of near-surface currents (arrows show direction only). The high-resolution monthly sea surface temperature and current data $\left(0.1^{\circ} \times 0.1^{\circ}\right)$ were obtained from the FRA-ROMS general ocean circulation model (Fisheries Research Agency of Japan) habitat use in relation to environmental parameters to provide new information on the spawning ecology of this species. As such, Fig. 2b,c shows the daily distribution of this PBF during August plotted with the satellite-derived subsurface temperature (at a $50 \mathrm{~m}$ depth) and surface current velocity and direction. This tagged PBF moved southward to the region around Oki Island before heading to offshore waters northwest of the island in the summer. This PBF's movements occurred in the vicinity of a warm water mass $\left(>20.0^{\circ} \mathrm{C}\right.$ at a $50 \mathrm{~m}$ depth) within the centre of an eddy system derived from the Tsushima warm current. Subsequently, the PBF travelled throughout coastal waters west of Japan towards Tsushima Island between autumn and winter.

\subsection{Seasonal differences in vertical movements}

Seasonal changes in surface $T_{\mathrm{a}}$ appear to have influenced the vertical distribution of ID252 (Fig. 3). The daily mean surface $T_{\mathrm{a}}$ experienced by the tagged $\mathrm{PBF}$ increased from $15.7^{\circ} \mathrm{C}$ after its release in May to $24.6^{\circ} \mathrm{C}$ by early July, and it further increased to $29.5^{\circ} \mathrm{C}$ by the middle of August. Subsequently, the surface $T_{\mathrm{a}}$ rapidly decreased from $25.3-22.8^{\circ} \mathrm{C}$ by the middle of September and then decreased gradually to $13.4^{\circ} \mathrm{C}$ by the end of January (Fig. 3a). This tagged PBF spent $42.5 \%$ of the daytime at depths shallower than $10 \mathrm{~m}$ during the early summer, when the surface $T_{\mathrm{a}}$ was below $24.0^{\circ} \mathrm{C}$, and $20.9 \%$ during the autumnwinter months (Fig. 3b). Conversely, its utilization of the surface layer was notably lower $(5.5 \%)$ during the summer months before and after the peak surface $T_{\mathrm{a}}$ was recorded (Fig. $3 \mathrm{~b}$ ). The early summer and autumn-winter months in the central Sea of Japan are typified by vertical mixing of the water column and cooling of the surface layer, and under these conditions, this tagged PBF swam at mean $( \pm \mathrm{SD})$ depths of $24.1 \pm 13.4$ and $36.5 \pm 8.9 \mathrm{~m}$, respectively (Fig. 3c). In contrast, a strong shallow thermocline develops during the summer, and this PBF swam deeper on average $(48.9 \pm 12.2 \mathrm{~m}$; Steel-Dwass test, $\mathrm{p}<0.01$ ), just below the thermocline. Across the tag record, this individual adjusted its swimming depth in response to gradual seasonal shifts in thermocline depth.

The tagged PBF (ID252) exhibited a distinct shift in vertical distribution between day and night when it was in the vicinity of the Sea of Japan spawning grounds. Fig. 4 demonstrates a representative $6 \mathrm{~d}$ selection of time-series swimming behaviour $(5 \mathrm{~s}$ sampling interval) plotted with $T_{\mathrm{a}}$ and $T_{\mathrm{b}}$ during the 


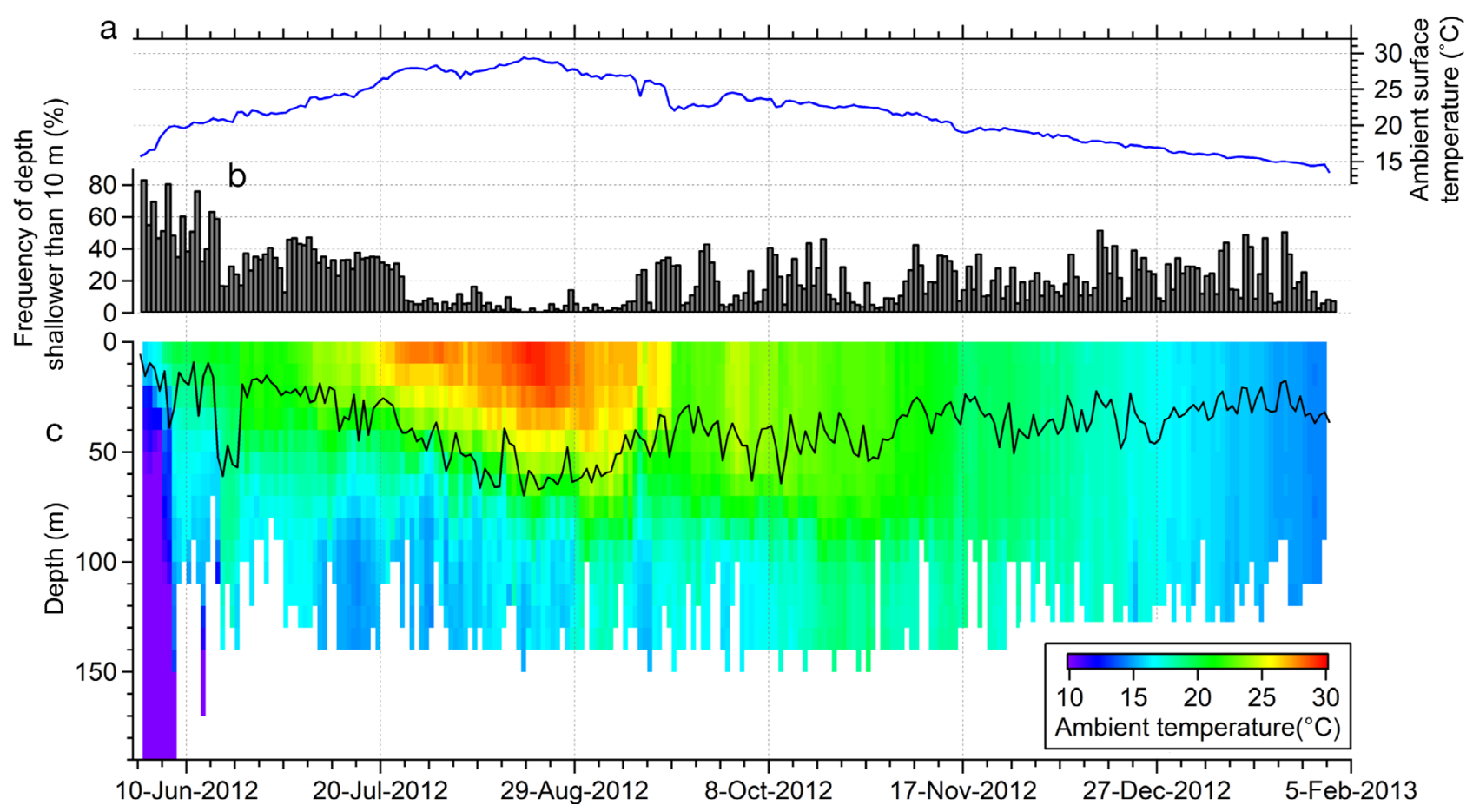

Fig. 3. (a) Daily mean surface ambient water temperature $(0-10 \mathrm{~m})$, (b) frequency of swimming depth shallower than $10 \mathrm{~m}$, and (c) mean swimming depth with water column temperatures recorded by the tagged PBF (ID252). Colours indicates the ambient water temperature $\left({ }^{\circ} \mathrm{C}\right)$ recorded by the tagged $\mathrm{PBF}$

early summer (surface $T_{\mathrm{a}}<24^{\circ} \mathrm{C}$; 31 May to 9 July) (Fig. 4a), summer (surface $T_{\mathrm{a}} \geq 24^{\circ} \mathrm{C} ; 10$ July to 16 September) (Fig. 4b), and autumn-winter (surface $T_{\mathrm{a}}<24^{\circ} \mathrm{C}_{i} 17$ September to 31 January) (Fig. $4 \mathrm{c}$ ) periods. When the daily mean surface $T_{\mathrm{a}}$ was below $24^{\circ} \mathrm{C}$ in the early summer and autumn-winter periods, this tagged PBF primarily swam near the surface and frequently dove deeper to $120 \mathrm{~m}$ depth at dawn, but the variability of $T_{\mathrm{a}}$ with diving behaviour was low (Fig. 4a,c). Conversely, when surface $T_{\mathrm{a}}$ exceeded $24^{\circ} \mathrm{C}$ in summer, this tagged PBF frequently dove to over $30 \mathrm{~m}$ and often remained at depth in cooler waters at approximately $15^{\circ} \mathrm{C}\left(T_{\mathrm{a}}\right)$ for several hours during the daytime (Fig. 4b). During the night-time, this PBF dramatically increased its utilization of warm surface waters, and its $T_{\mathrm{b}}$ increased significantly during these shallow excursions.

The time-series of swimming behaviours for the 4 other archival-tagged PBF are shown in Fig. 4d-i. In early summer, when the surface $T_{\mathrm{a}}$ was below $24.0^{\circ} \mathrm{C}$, the daily mean swimming depths of the tagged PBF were mostly shallow (ID260, $31.8 \pm 31.3 \mathrm{~m}$; ID256, $14.1 \pm 19.6 \mathrm{~m}$; ID259, $17.7 \pm 23.4 \mathrm{~m}$; ID1723, $11.0 \pm 13.0 \mathrm{~m}$ ) (Fig. $4 \mathrm{~d}, \mathrm{e}, \mathrm{g}, \mathrm{h})$. We were able to track 2 of these individuals (ID256 and ID1723) through midsummer when they were distributed off the northern coast of Honshu. Although the daily mean surface $T_{\mathrm{a}}$ rose above $24.0^{\circ} \mathrm{C}$ on 19 July 2012 (ID256) and 11 July 2017 (ID1723) after release, the $T_{\mathrm{a}} \mathrm{s}$ during the summer remained relatively low $(23.9 \pm 1.2$ and 24.8 $\pm 1.3^{\circ} \mathrm{C}$, respectively) compared with the $T_{\mathrm{a}} \mathrm{s}$ experienced by ID252 $\left(27.1 \pm 1.4^{\circ} \mathrm{C}\right)$ throughout the summer (Fig. 4f,i). On average, these 2 tagged PBF swam near the surface layer in the summer (ID256, $15.5 \pm$ $30.5 \mathrm{~m}$; ID1723, $11.2 \pm 14.5 \mathrm{~m}$ ), and they occasionally dove over $100 \mathrm{~m}$ into cool waters $\left(<15^{\circ} \mathrm{C}\right)$ during the daytime. Summaries of the swimming depth, $T_{a}$ and $T_{\mathrm{b}}$ data for all individuals (including PAT-tagged PBF) are shown in Table 1.

We proceeded to investigate these seasonal and diel patterns in the PBF's habitat utilization more generally by examining its daytime/night-time swimming depth distribution alongside mean $T_{\mathrm{a}}$ and $T_{\mathrm{b}}$ profiles for each season (Fig. 5). During the early summer when the thermocline depth ranged from 40-50 $\mathrm{m}$, the tagged PBF (ID252) spent most of its time in the mixed layer (from the surface to the thermocline depth) both during the daytime (79.6\%) and at night (89.0\%) (Fig. 5a). During this time, the mean $T_{\mathrm{b}}$ recorded within the surface layer $(0-10 \mathrm{~m})$ was $25.0 \pm 3.0^{\circ} \mathrm{C}$, which was $4.6^{\circ} \mathrm{C}$ higher than the mean $T_{\mathrm{a}}$. The vertical mixing of the water column during 
a ID252: Early summer

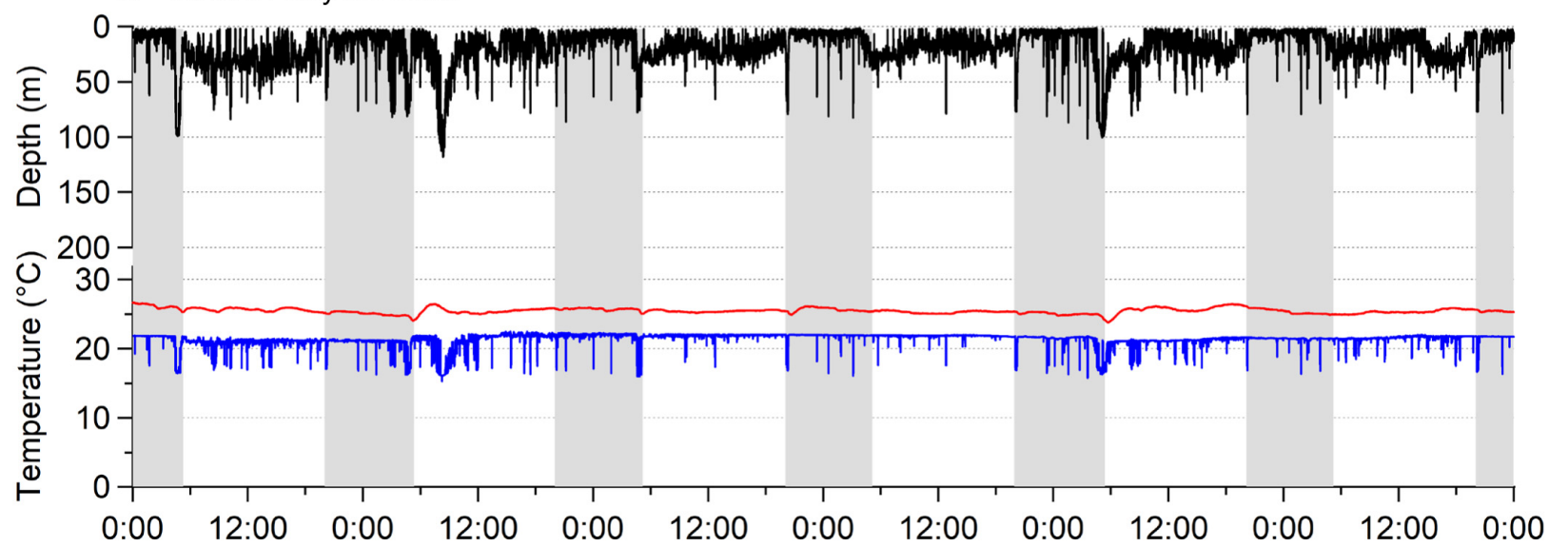

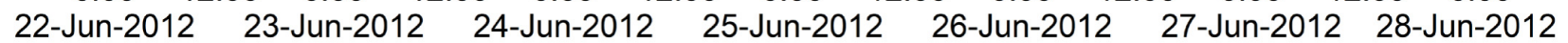

b ID252: Summer

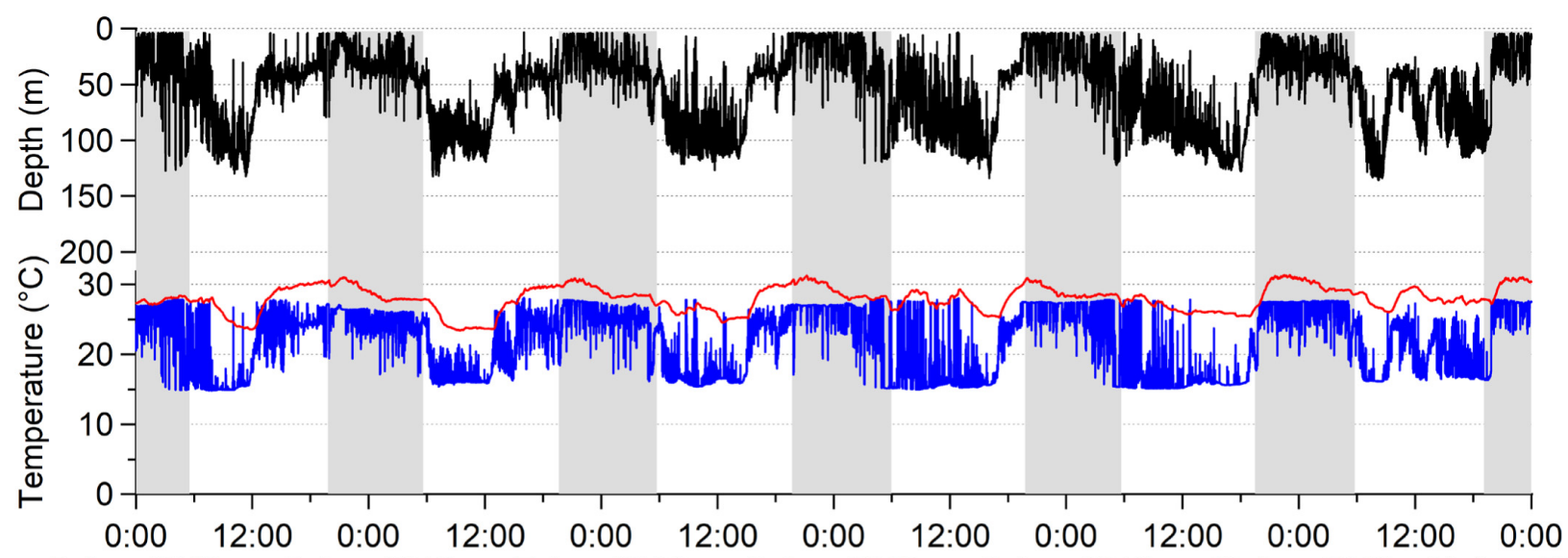

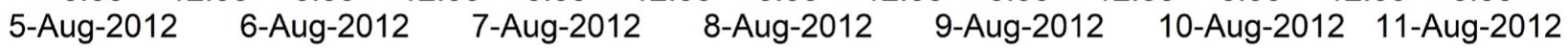

C ID252: Autumn-winter

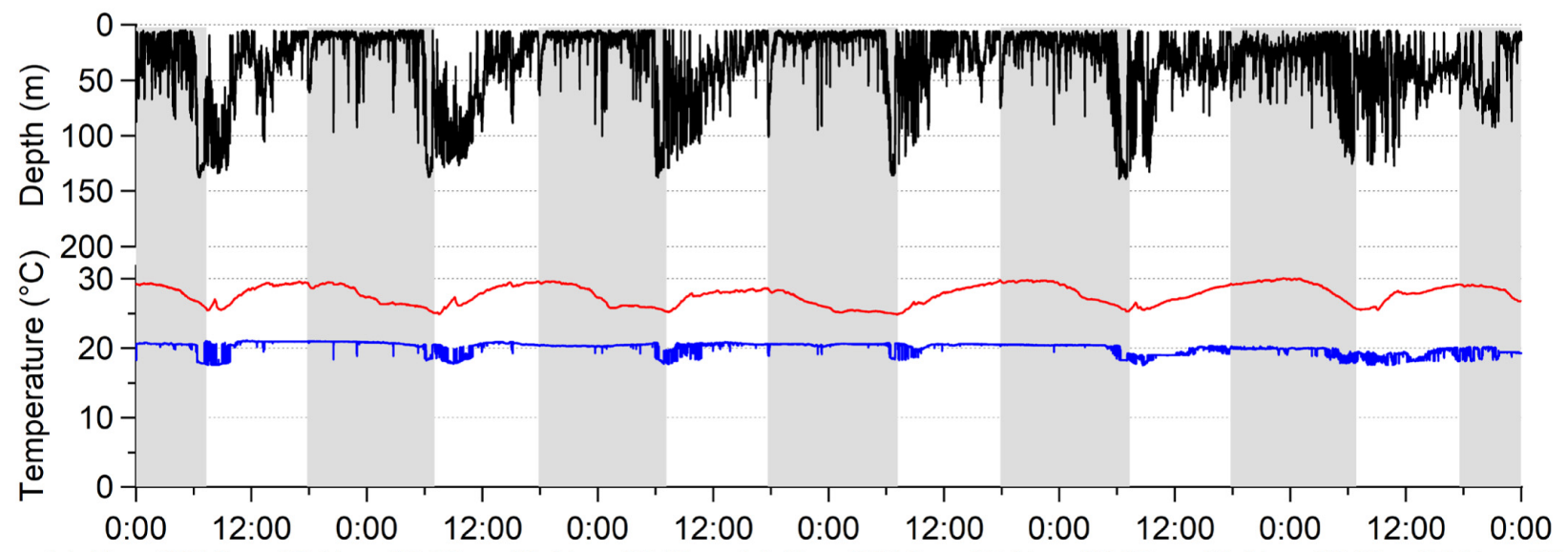

11-Nov-2012 12-Nov-2012 13-Nov-2012 14-Nov-2012 15-Nov-2012 16-Nov-2012 17-Nov-2012

Fig. 4. Time-series data (5 s sampling interval) of swimming depth (black), ambient water temperature (blue), and peritoneal cavity temperature (red) of the tagged PBF (ID252) when (a) daily mean ambient surface temperatures were below $24^{\circ} \mathrm{C}$ in the early summer and (c) autumn-winter periods and (b) when they exceeded $24^{\circ} \mathrm{C}$ during the summer spawning period of 2012 . (d-i) Time-series data for all archival tagged fish (ID260, 256, 259, 1723) for each season. Vertical grey bars: night-time 


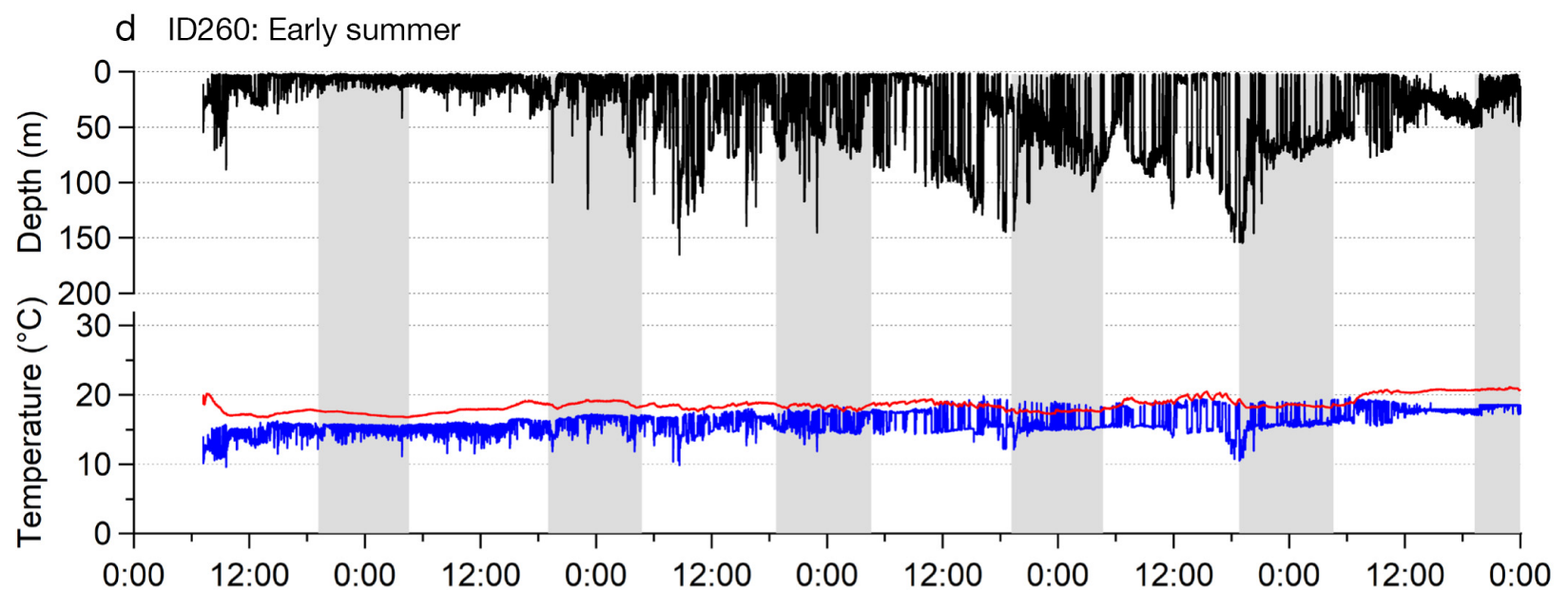

24-May-2012 25-May-2012 26-May-2012 27-May-2012 28-May-2012 29-May-2012 30-May-2012 e ID256: Early summer

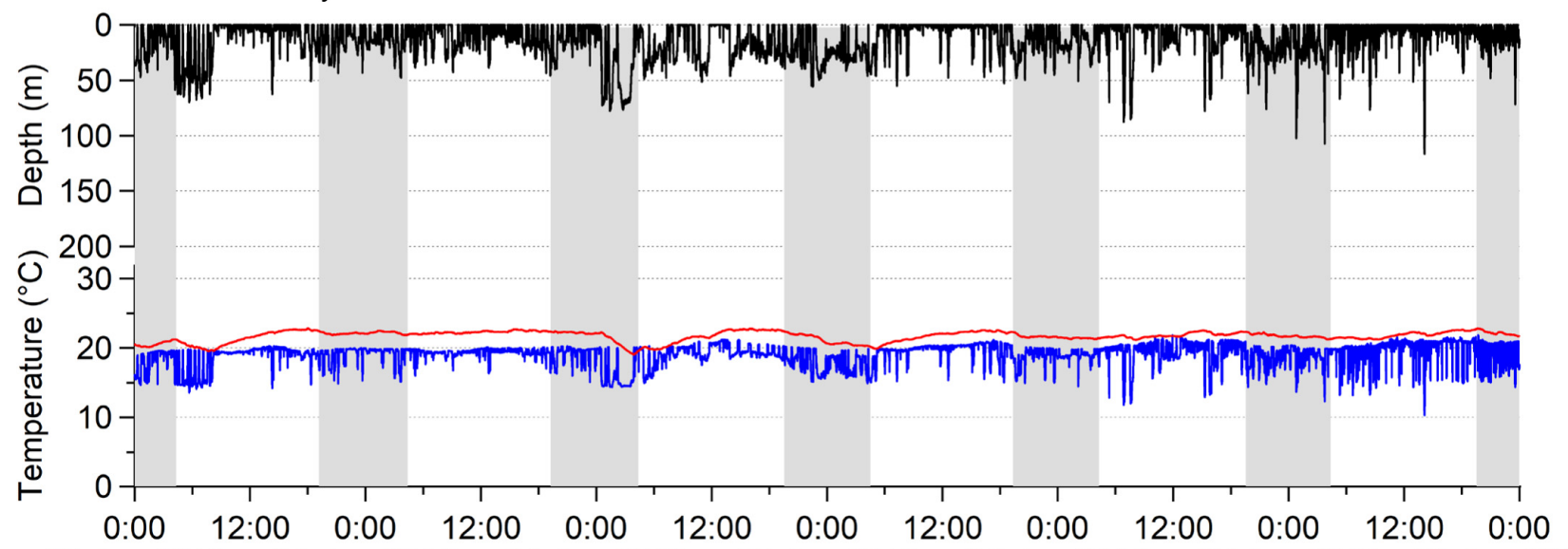

22-Jun-2012 23-Jun-2012 24-Jun-2012 25-Jun-2012 26-Jun-2012 27-Jun-2012 28-Jun-2012

f ID256: Summer

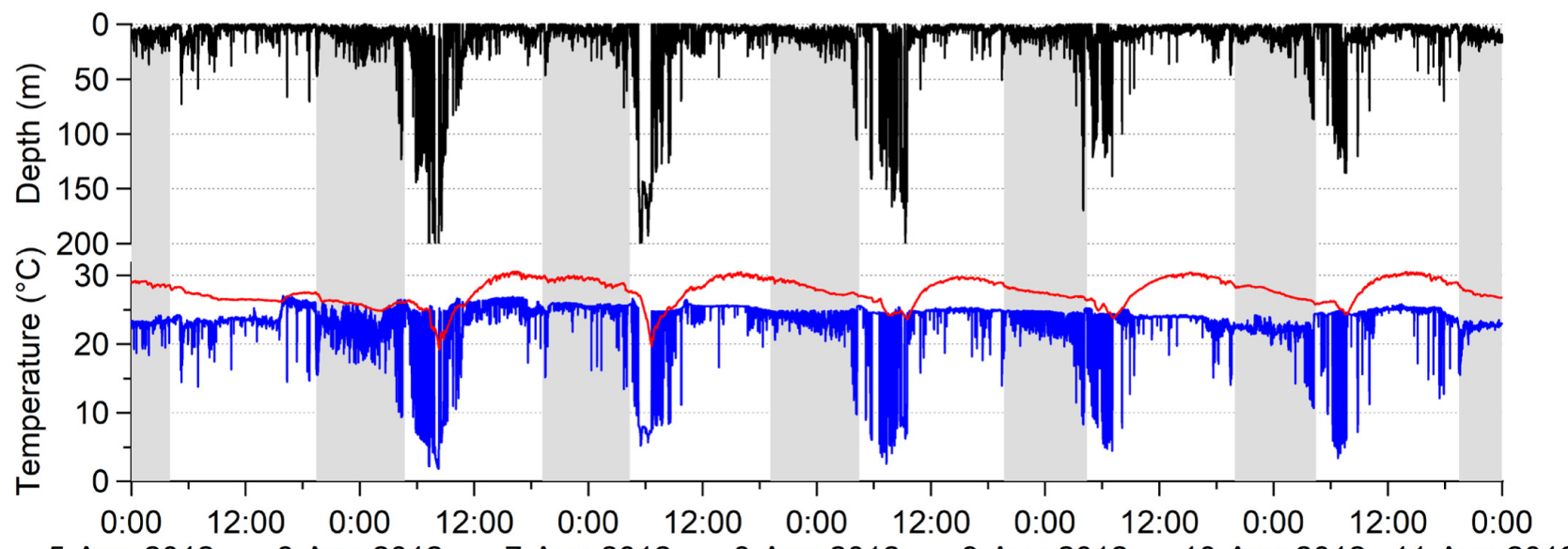

5-Aug-2012 6-Aug-2012 7-Aug-2012 8-Aug-2012 9-Aug-2012 10-Aug-2012 11-Aug-2012

Fig. 4. (continued)

the autumn and winter months deepened the thermocline depth to 80-90 $\mathrm{m}$, and as a result, this tagged PBF swam in a wider depth range in the sur- face zone (0-80 $\mathrm{m})$, both during the daytime $(87.4 \%)$ and at night $(96.0 \%$ ) (Fig. $5 \mathrm{c})$. The mean $T_{\mathrm{b}}$ recorded during this time $\left(26.6 \pm 2.8^{\circ} \mathrm{C}\right)$ was $7.3^{\circ} \mathrm{C}$ higher than 
9 ID259: Early summer

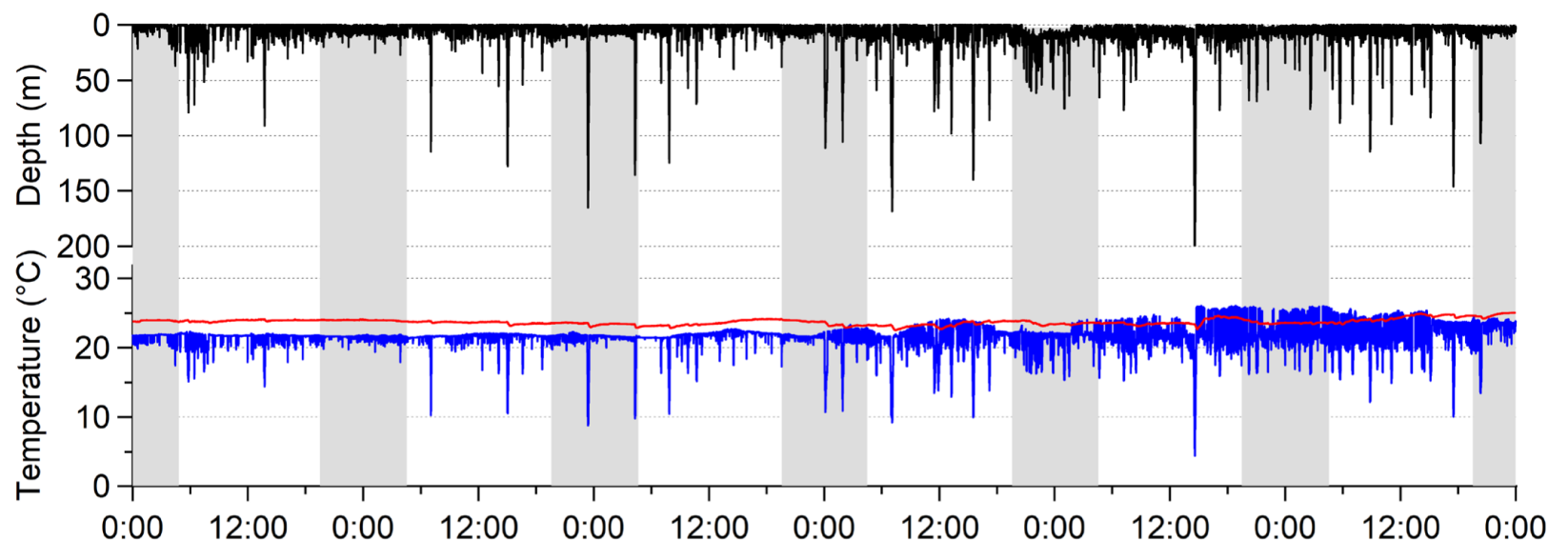

22-Jun-2014 23-Jun-2014 24-Jun-2014 25-Jun-2014 26-Jun-2014 27-Jun-2014 28-Jun-2014

h ID1723: Early summer

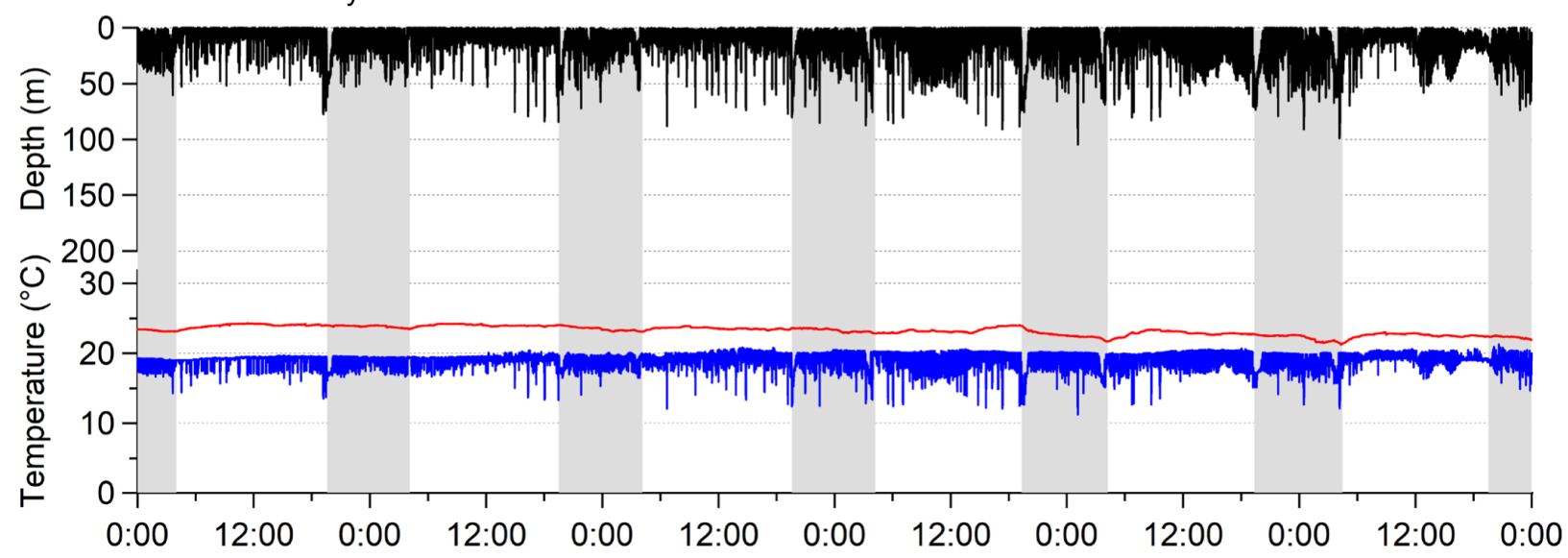

22-Jun-2017 23-Jun-2017 24-Jun-2017 25-Jun-2017 26-Jun-2017 27-Jun-2017 28-Jun-2017

i ID1723: Summer

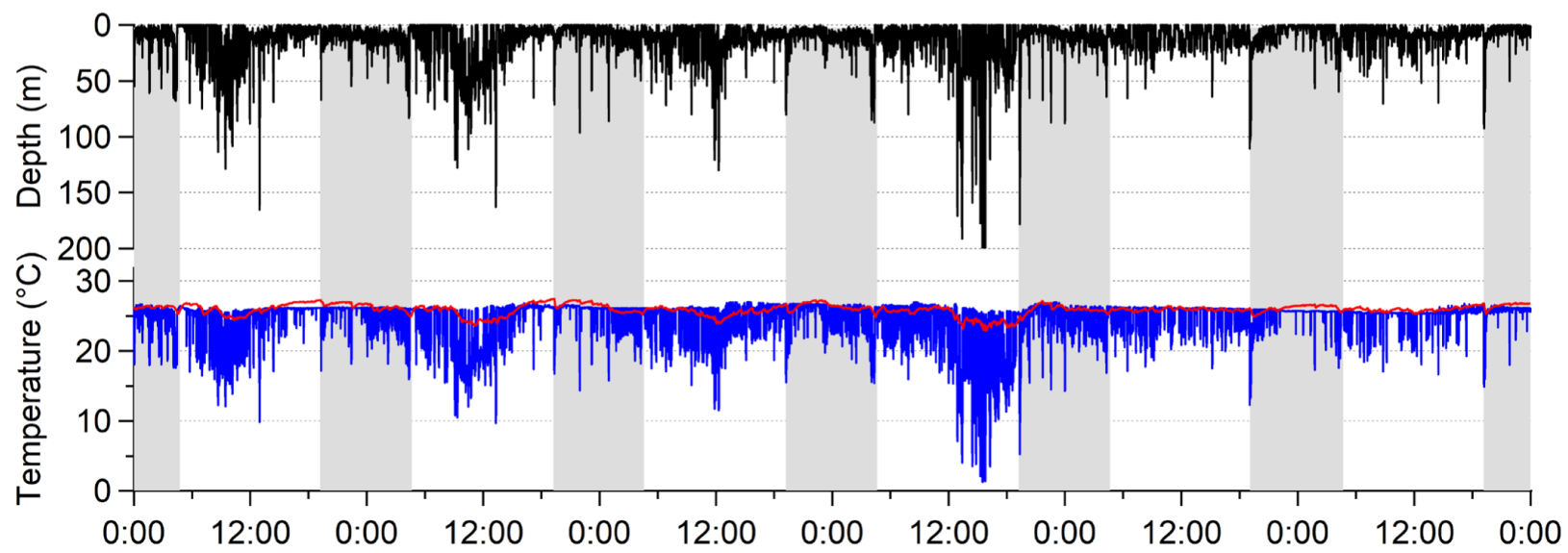

12-Aug-2017 13-Aug-2017 14-Aug-2017 15-Aug-2017 16-Aug-2017 17-Aug-2017 18-Aug-2017

Fig. 4. (continued)

the mean surface $T_{\mathrm{a}}$. Conversely, when a shallow (30$40 \mathrm{~m}$ ) thermocline developed during the summer and the surface $T_{\mathrm{a}}$ increased $\left(26.0 \pm 1.5^{\circ} \mathrm{C}\right.$ at a $0-10 \mathrm{~m}$ depth), this PBF exhibited a bimodal daytime depth distribution between 40-50 and 100-110 $\mathrm{m}$ where the mean $T_{\mathrm{a}}$ was $23.7 \pm 2.4$ and $16.2 \pm 1.0^{\circ} \mathrm{C}$, 

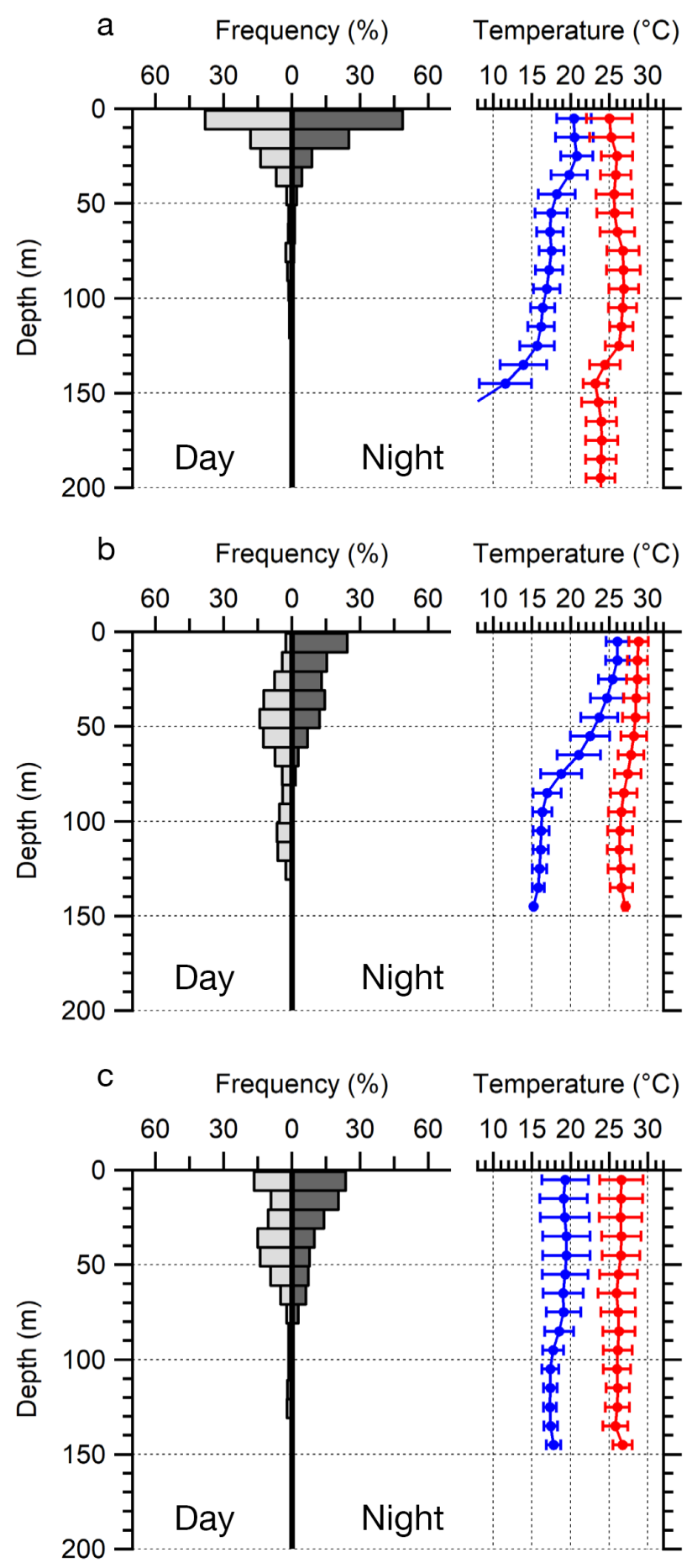

Fig. 5. Frequency distributions of the swimming depth of Pacific bluefin tuna (ID252) between day and night with vertical profiles of mean $( \pm \mathrm{SD})$ ambient water temperature $\left(T_{\mathrm{a}}\right.$ blue) and peritoneal cavity temperature ( $T_{\mathrm{b}}$, red) in (a) early summer (31 May to $9 \mathrm{July)}$ (surface $T_{\mathrm{a}}<24^{\circ} \mathrm{C}$ ), (b) summer (10 July to 16 September) (surface $T_{\mathrm{a}} \geq 24^{\circ} \mathrm{C}$ ), and (c) autumn-winter (17 September to 31 January) (surface $T_{\mathrm{a}}<$ $\left.24^{\circ} \mathrm{C}\right)$. Aggregated data from $(\mathrm{d}, \mathrm{e})$ archival-tagged $(\mathrm{n}=4)$ and $(\mathrm{f}-\mathrm{h})$ PAT-tagged $(\mathrm{n}=18 ;>3 \mathrm{~d})$ fish are shown for each season

Fig. 5. (continued on next page) respectively (Fig. 5b). This PBF spent little time in the mixed layer during the daytime $(16.7 \%$ spent between 0 and $30 \mathrm{~m}$ ); however, during the summer nights, it exhibited high utilization of the surface habitat and frequently ventured below the thermocline $(<30 \mathrm{~m})$. This PBF spent $54.3 \%$ of the nighttime within the mixed layer and $45.7 \%$ of the nighttime below the thermocline during the summer. During this time, the mean $T_{\mathrm{b}}$ recorded in the mixed layer was extremely high $\left(28.8 \pm 1.2^{\circ} \mathrm{C}\right.$ at the surface), with a maximum $T_{\mathrm{b}}$ record of $32.1^{\circ} \mathrm{C}$. The mean $T_{\mathrm{b}}$ recorded within the mixed layer was only $2.8^{\circ} \mathrm{C}$ warmer than the surface $T_{\text {ai }}$ however, it was $10.2^{\circ} \mathrm{C}$ warmer than the $T_{\mathrm{a}}$ on average when the PBF dove to cooler waters below the thermocline (16.2 \pm $1.0^{\circ} \mathrm{C}$ at $100-110 \mathrm{~m}$ depth) (Fig. 5b).

The vertical distributions of $T_{\mathrm{a}} \mathrm{s}$ and $T_{\mathrm{b}} \mathrm{s}$ for the archival-tagged PBF (not including ID252) and PATtagged PBF records $(n=18 ;>3 d)$ are shown for each season in Fig. 5d-h. Overall, the PBF were distributed in the surface mixed layer (0-10 m depth) during the daytime (49.2-62.8\%) and night-time (48.3-68.5\%) in both the early summer (archivaltagged $\mathrm{PBF}, \mathrm{n}=4$, Fig. 5d; PAT-tagged $\mathrm{PBF}, \mathrm{n}=18$, Fig. 5f) and summer (archival-tagged $\mathrm{PBF}, \mathrm{n}=2$, Fig. 5e; PAT-tagged PBF, $\mathrm{n}=5$, Fig. 5g). They experienced high $T_{\mathrm{a}}\left(25.1 \pm 0.9^{\circ} \mathrm{C}\right.$ at a $0-10 \mathrm{~m}$ depth $)$ throughout the summer season (Fig. 4f,i), while their mean $T_{\mathrm{b}}$ was $26.5 \pm 1.4^{\circ} \mathrm{C}$ at a $0-10 \mathrm{~m}$ depth (Fig. 5e). When the thermocline deepened to 40-50 m during the autumn-winter, the PBF (PAT-tagged PBF, $\mathrm{n}=1$, Fig. 5h) exhibited wider depth distributions, ranging between 0-40 $\mathrm{m}$ during the day $(75.0 \%)$ and at night $(73.5 \%)$.

\subsection{Diel patterns of swimming behaviour and $T_{a}$}

To examine daily differences in the daytime and night-time swimming behaviours exhibited by the tagged PBF (ID252), we investigated the relationships between the utilization of depths shallower than $10 \mathrm{~m}$ and (1) the mean $T_{\mathrm{a}}$ experienced by this PBF and (2) this PBF's mean $T_{\mathrm{b}}$ elevation above the mean $T_{\mathrm{a}}$ (Fig. 6). Across all seasons, this PBF markedly decreased its utilization of surface waters during the daytime as surface $T_{\mathrm{a}}$ increased (Spearman rank correlation: $\mathrm{r}_{\mathrm{S}}=-0.70, \mathrm{n}=246 \mathrm{~d}, \mathrm{p}<$ 0.001) (Fig. 6a). Furthermore, surface swimming behaviours $(0-10 \mathrm{~m})$ were rarely observed $(3.3 \pm$ $4.3 \%$ ) when the surface $T_{\mathrm{a}}$ exceeded $24.0^{\circ} \mathrm{C}$ during the summer. The $\mathrm{PBF}^{\prime} \mathrm{s}$ thermal elevation above $T_{\mathrm{a}}$ decreased as surface $T_{\mathrm{a}}$ increased $\left(\mathrm{r}_{\mathrm{S}}=\right.$ 


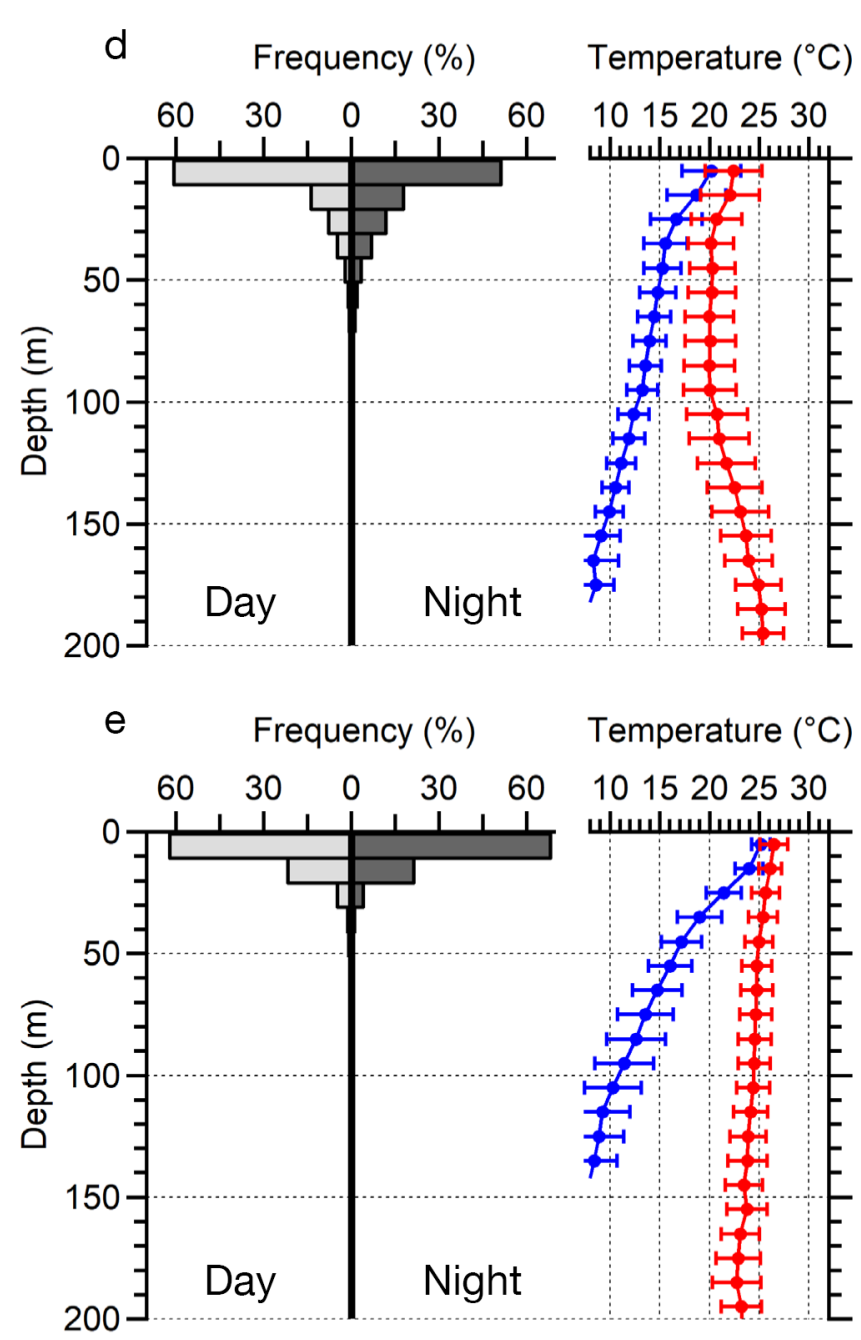

Fig. 5. (continued)

$-0.78, \mathrm{p}<0.001)$. These mean temperature differences were $4.6 \pm 1.3^{\circ} \mathrm{C}$ in the early summer and $7.4 \pm 2.0^{\circ} \mathrm{C}$ in the autumn-winter when the surface $T_{\mathrm{a}}$ was below $24.0^{\circ} \mathrm{C}$, while in summer it was only $1.5 \pm 1.8^{\circ} \mathrm{C}$ (Fig. 6b). During the nighttime, we did not detect a significant correlation between the swimming depth and surface $T_{\mathrm{a}}$ experienced by this PBF $\left(r_{S}=-0.18, p=0.004\right)$; however, the utilization of the surface layer decreased as the surface $T_{\mathrm{a}}$ approached $30.0^{\circ} \mathrm{C}$ (Fig. 6c). The mean frequency in the summer was higher than that in the daytime $(18.7 \pm 17.7 \%)$. The absolute difference between PBF $T_{\mathrm{b}}$ and $T_{\mathrm{a}}$ decreased significantly as the surface $T_{\mathrm{a}}$ warmed across all night-time temperature records $\left(\mathrm{r}_{\mathrm{S}}=-0.74, \mathrm{p}<\right.$ $0.001)$, and the values were $4.8 \pm 1.6^{\circ} \mathrm{C}$ in early summer and $6.9 \pm 2.1^{\circ} \mathrm{C}$ in autumn-winter, compared with $1.8 \pm 1.6^{\circ} \mathrm{C}$ in summer (Fig. 6d).
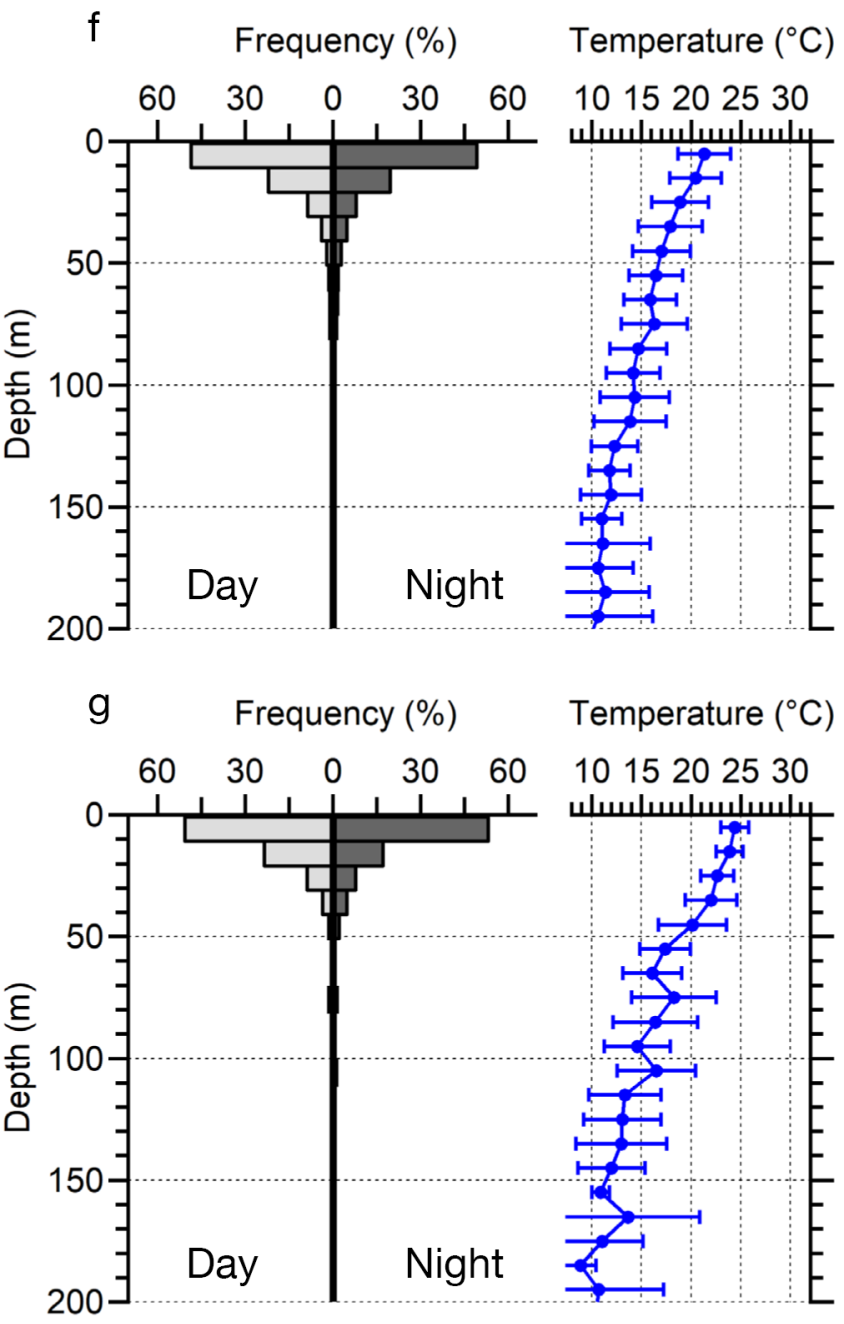

h Frequency $(\%) \quad$ Temperature $\left({ }^{\circ} \mathrm{C}\right)$

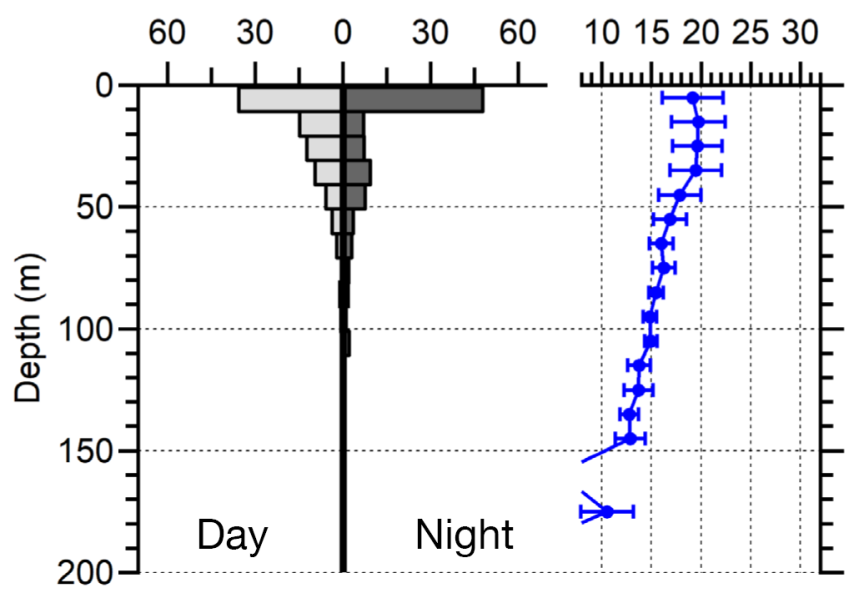

\subsection{Whole-body heat transfer coefficient, $k$}

The $k$ and $\frac{d T_{m}}{d t}$ of the tagged PBF (ID252) were estimated using the heat budget model (Fig. 7). In the 

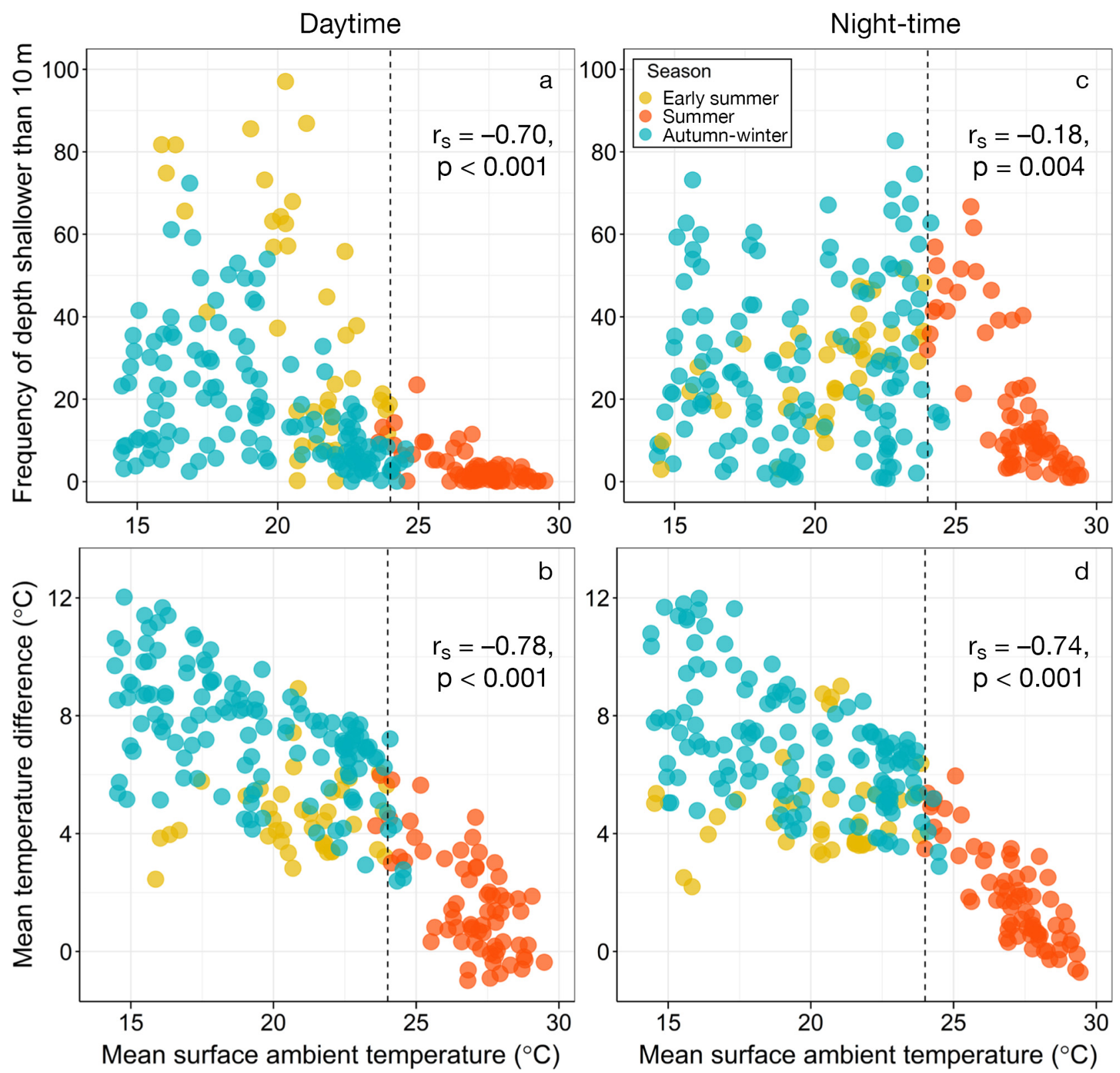

Fig. 6. Daily frequency at depths shallower than $10 \mathrm{~m}$ and temperature difference (peritoneal cavity temperature, $T_{\mathrm{b}}$, minus ambient water temperature, $T_{\mathrm{a}}$ ) $\left({ }^{\circ} \mathrm{C}\right)$ of the tagged Pacific bluefin tuna (PBF) (ID252) plotted with surface $T_{\mathrm{a}}$ during $(\mathrm{a}, \mathrm{b})$ daytime and $(\mathrm{c}, \mathrm{d})$ night-time $(\mathrm{n}=246 \mathrm{~d})$. Spearman rank correlation test scores $\left(\mathrm{r}_{\mathrm{S}}\right)$ are also shown. Vertical dotted lines: preferred temperature for PBF spawning $\left(\geq 24^{\circ} \mathrm{C}\right)$ (Okochi et al. 2016, Ohshimo et al. 2017)

early summer season, the mean values of $k$ were 4.91 $\times 10^{-4} \mathrm{~s}^{-1}$ during the day and $3.80 \times 10^{-4} \mathrm{~s}^{-1}$ at night. In the summer season, the mean values of $k$ were $4.28 \times 10^{-4} \mathrm{~s}^{-1}$ during the day and $6.10 \times 10^{-4} \mathrm{~s}^{-1}$ at night. In the autumn-winter season, the mean values of $k$ were $3.62 \times 10^{-4} \mathrm{~s}^{-1}$ during the day and $3.41 \times$ $10^{-4} \mathrm{~s}^{-1}$ at night.

We observed a significant diel difference in the average $k$ coefficient value for ID252 measured for every $12 \mathrm{~h}$ period during the summertime (paired samples $t$-test, $t=-9.302, \mathrm{df}=66, \mathrm{p}<0.001$ ) (Fig. 8). On the other hand, the average $k$ coefficient value for ID256 and ID1723 showed no significant diel difference during the summer months (ID256 paired samples $t$-test, $t=0.112, \mathrm{df}=22, \mathrm{p}>0.05$; ID1723 paired samples $t$-test, $t=-0.776, \mathrm{df}=45, \mathrm{p}>0.05$ ).

These results demonstrate that individual ID252 exhibited behaviours in response to the diel cycle, 

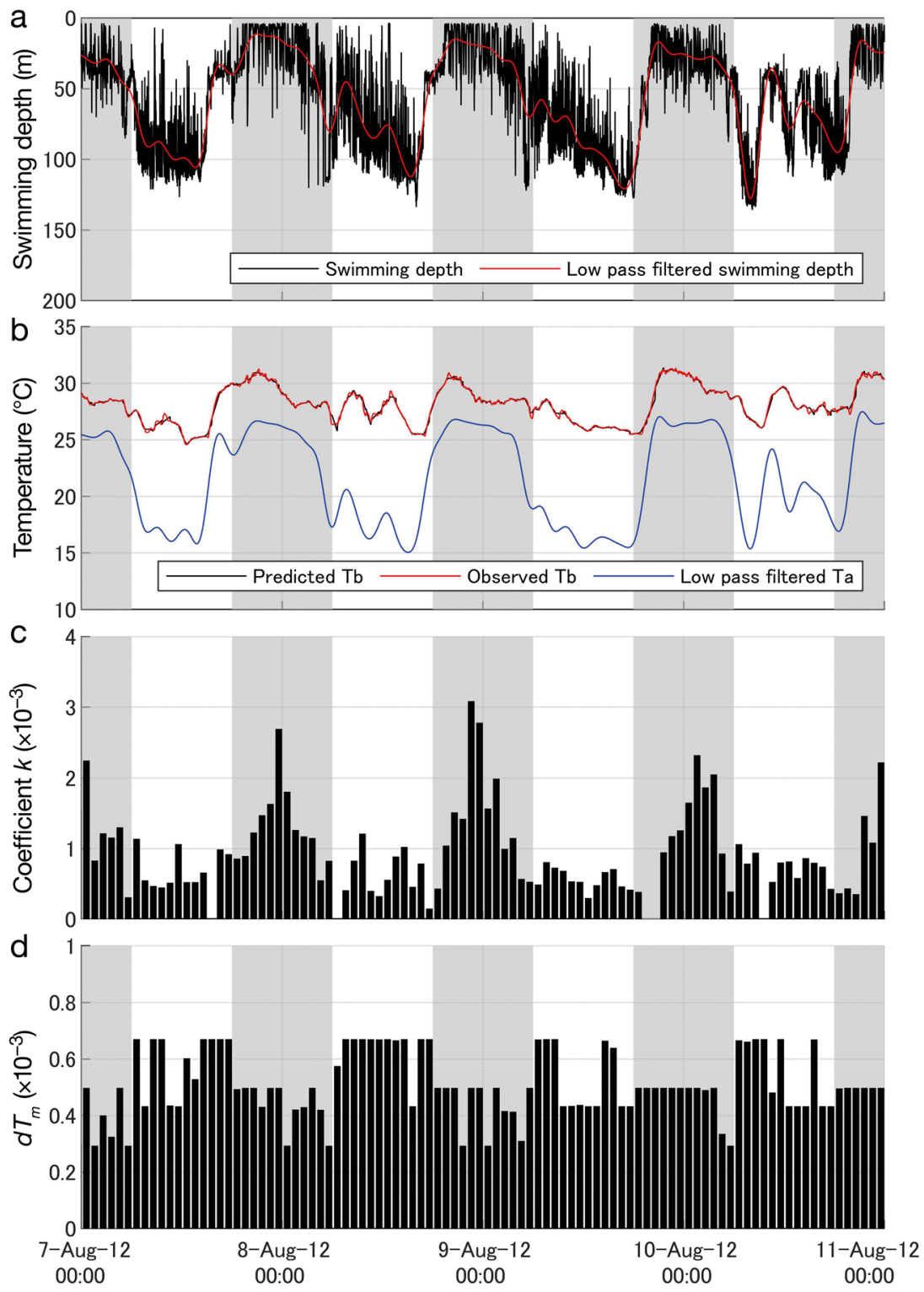

Fig. 7. Time-series data of (a) swimming depth, (b) ambient temperature with the low-pass value $\left(T_{\mathrm{a}}\right)$, along with observed and predicted peritoneal cavity temperature $\left(T_{\mathrm{b}}\right)(\mathrm{c})$ whole-body heat transfer coefficient $(k)$, and $(\mathrm{d})$ internal heat production $\left(d T_{m}\right)$ of tagged PBF (ID252). The predicted values of peritoneal cavity temperature and $k$ were estimated using an optimized heat budget model. Vertical grey bars: night-time

especially during the summer nights in the known spawning season in the Sea of Japan.

\section{DISCUSSION}

This is the first study to show long-term records (246 d) of swimming behaviour of an adult PBF (ID252) throughout the spawning period in the Sea of Japan. The aim of this study was to reveal the broad horizontal movements of adult PBF in the Sea of Japan using archival and PAT tags as well as to describe the fine-scale characteristics of habitat utilization in one of the important spawning areas for this species. We observed 2 dominant movement patterns within the Sea of Japan: one where tuna moved towards the centre of the Sea of Japan near Oki Island and another where they moved along the northern coast of Honshu between Niigata Prefecture and the Tsugaru Strait (Fig. 1). Both of these regions may represent spawning habitats for adult PBF (Okochi et al. 2016, Ohshimo et al. 2017, 2018), as revealed by Okochi et al. (2016), who reported $95 \%$ maturity rates in PBF with an average FL of $133.6 \mathrm{~cm}$ captured in the Sea of Japan by purse seine fisheries. These previous results suggest that the PBF tagged in this study (average FL: $142.2 \mathrm{~cm}$ ) were mostly mature. The region offshore of Oki Island is an especially well-documented spawning ground, as demonstrated by long-running surveys (1956-1989, 1979-1988, 1999-2004, and 20092015) of larval PBF abundance in the Sea of Japan (Tanaka et al. 2007, Abe et al. 2014, Ohshimo et al. 2017). We note that the horizontal habitat usage results shown herein reflect a densityweighted bias around the tagging site resulting from the relatively shortterm tag recoveries/early PAT tag pop-offs. Further research is needed to clearly define the spawning habitat utilized by adult PBF in the Sea of Japan.

During the autumn and winter period, adult PBF were dispersed widely across the Sea of Japan (near Tsushima Island or the Tsugaru Strait) (Fig. 1). One PAT-tagged PBF spent 6 mo in the Sea of Japan before migrating through the Tsugaru Strait in the winter to reach the vicinity of the Shatsky Rise (Fig. S1). This result suggests that some PBF may have a particular tendency to exploit distant foraging areas related to topographic features (Boustany et al. 2010, Fujioka et al. 2018b). Further research is needed to understand the movements of adult PBF within and outside of the Sea of Japan. 
Despite limited evidence stemming from one tagged PBF, our results suggest that oceanographic features and SSTs influence habitat selection by adult PBF during the spawning season. In summer, the tagged PBF (ID252) spent most of its time in the centre of the Sea of Japan, where warm eddy features persisted during the spawning season (Fig. 2). Similar eddy features have been shown to play an important role in the spawning ecology of Atlantic bluefin tuna Thunnus thynnus, and it is proposed that the oceanographical conditions within these structures support enhanced larval growth and survival (Teo et al. 2007b, Bakun 2013, Muhling et al. 2013). These dynamic current systems may also transport PBF larvae to warm nursery waters (Kitagawa et al. 2010, Fujioka et al. 2015) where they may become entrained in food-rich coastal habitats (Tanaka et al. 2007, Kodama et al. 2017) without being advected to cooler offshore waters. Indeed, in previous studies, oceanographic models have been generated based on larval thermal preference that simulate the horizontal dispersal of PBF larvae with good predictive capacity (Abe et al. 2014). Regarding the thermal conditions for PBF spawning, it is commonly assumed that adult tuna primarily spawn at SSTs above $24^{\circ} \mathrm{C}$ (Schaefer 2001, Okochi et al. 2016), and previous laboratory experiments suggest that $25^{\circ} \mathrm{C}$ is the optimal water temperature for PBF egg hatching (Miyashita et al. 2000). Warm temperatures likely provide metabolic benefits to PBF larvae and therefore enable faster growth during this key life stage (Tanaka et al. 1996). In the present study, the daily mean surface $T_{\mathrm{a}}$ experienced by a tagged PBF (ID252) ranged from $24.6-29.5^{\circ} \mathrm{C}$ during the summer (Fig. 3). Therefore, these results corroborate the hypothesis that warm eddy features can be selected by adult PBF to provide optimal conditions for larval growth and survival. Only through continued tagging efforts and larval surveys will we be able to clearly understand the utilization of such oceanographic features for PBF spawning.

Our horizontal movement findings demonstrated that the adult PBF (ID252) selected warm-core eddy environments in the Sea of Japan; however, this tagged PBF consistently avoided these warm surface waters during the daytime by diving into deeper waters (Figs. $4 \mathrm{~b} \& 5 \mathrm{~b}$ ). When surface $T_{a}$ was less than $24.0^{\circ} \mathrm{C}$ (early summer and autumn-winter), the swimming depth of this tagged PBF was closely related to seasonal changes in the thermocline depth (Figs. 4a,c \& 5a,c). Our results suggest that all the tagged PBF preferred to utilize the mixed layer when conditions were cooler (Figs. 4 \& 5), a finding consistent with those of many previous PBF tagging studies (Kitagawa et al. 2000, 2004, Itoh et al. 2003, Furukawa et al. 2014, 2017). Conversely, when the surface $T_{\mathrm{a}}$ rose above $24.0^{\circ} \mathrm{C}$ in the summer spawning season, the tagged PBF (ID252) frequently avoided warm surface water (mean: $26.0^{\circ} \mathrm{C}$ ) and swam below the wide thermocline $(30-40 \mathrm{~m})$ during the daytime (Fig. 5b). Interestingly, during night-time, this PBF ventured into the warm mixed surface layer but also dove below the thermocline.

We observed an interesting discrepancy in the patterns of vertical habitat use between a subset of the tagged PBF. During the summer, some tagged PBF (ID256, ID1723, and ID16P2015) remained in the surface layer throughout the entire day (Figs. 4f,i \& 5e,g) when distributed off the northern coast of Honshu in relatively warm surface waters (mean $24.4-25.1^{\circ} \mathrm{C}$ ) in a shallow (10-20/20-30 $\mathrm{m}$ ) thermocline environment. Conversely, the PBF (ID252) that visited the known spawning grounds in the summer months spent most of the daytime avoiding the warm surface layer (mean: $26.0^{\circ} \mathrm{C}$ ). The more northerly distributed PBF demonstrated a significant tolerance for longterm exposure to high surface $T_{\mathrm{a}} \mathrm{s}$ relative to the $\mathrm{PBF}$, but we found that the internal $T_{b} \mathrm{~S}$ of the northern group was noticeably cooler (mean: $26.5^{\circ} \mathrm{C}$ ) relative to the $T_{\mathrm{b}}$ of the PBF on the spawning grounds (mean: $28.8^{\circ} \mathrm{C}$ ). This high average $T_{\mathrm{b}}$ is close to the hypothesized upper thermal limit of $30^{\circ} \mathrm{C}$, which we presume explains this individual PBF's need to behaviourally thermoregulate by remaining below the warm mixed layer.

Little is known regarding the diel timing of bluefin spawning activity; however, it may occur primarily in the evening between 17:00 and 22:00 h (Masuma 2006, Okochi et al. 2016). Our results showed that $k$ was significantly higher at night during the summer spawning period (Figs. $7 \&$ 8), which supported the capability of the PBF to adjust their physiological response to avoid overheating in the high-temperature environment found in the summer spawning habitat. Despite these high ambient temperatures, the persistent evening excursions into the warm surface layer detected in this study may represent the spawning activity of adult PBF. However, novel techniques and analyses are needed to determine when spawning actually occurs as it is often a spontaneous and short-lived event. Future analyses should explore the role of the lunar cycle, which may regulate spawning activity due to its influence on the predation risk for eggs and larvae during night-time (Shimose et al. 2018). 


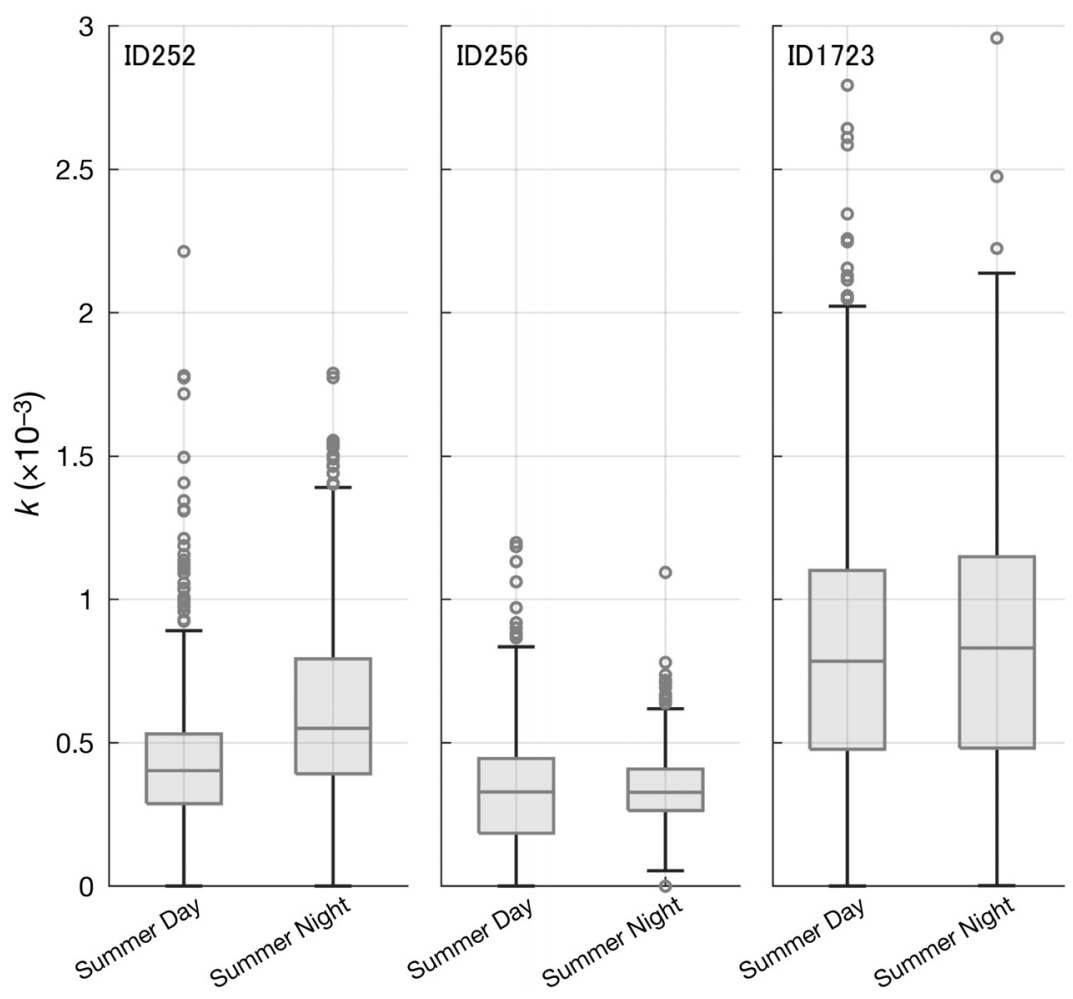

Fig. 8. Boxplots of diel differences in whole-body heat transfer coefficients $(k)$ of tagged PBF (ID252, ID256, and ID1723) estimated from the heat budget model in the spawning season (summer). There was a significant diel difference in the mean of $k$ for ID252 measured for every $12 \mathrm{~h}$ period during the summer months (paired samples $t$-test, $t=-9.302$, $\mathrm{df}=66, \mathrm{p}<0.001$ ). Horizontal line: median; top and bottom of boxes: third and first quartiles, respectively; whiskers: maximum and minimum; open circles: suspected outliers

These consistent, prolonged evening excursions into the warm surface layer likely presented a physiological challenge to the adult PBF (ID252) (Fig. 6). Blank et al. (2007) studied juvenile PBF in a swim tunnel respirometer and established a U-shaped correlation between $T_{\mathrm{a}}$ from $8-25^{\circ} \mathrm{C}$ and metabolic rate, with a minimum rate of oxygen consumption at $15^{\circ} \mathrm{C}$ $\left(175 \pm 29 \mathrm{mg} \mathrm{kg}^{-1} \mathrm{~h}^{-1}\right)$. Regional endothermy has been well documented in $\mathrm{PBF}$, which maintain higher body temperatures through the use of various counter-current heat exchange organs (Carey et al. 1971, Stevens et al. 1974, Kitagawa et al. 2006a). Kitagawa et al. (2006a) reported that the $T_{\mathrm{b}}$ of adult PBF was on average $5-7^{\circ} \mathrm{C}$ higher than $T_{\mathrm{a}}$. The ability of PBF to warm their bodies may provide an advantage under cooler conditions; however, in the warm spawning grounds, endothermy may exacerbate the physiological challenge of spawning. Therefore, bluefin tuna seem to have an impressive adaptive capacity to handle high temperatures (Fig. 6) through their diving behaviour (Figs. 4 \& 5) and thermal biology (Figs. $7 \&$ 8). For example, when Atlantic bluefin tuna arrive at the warm spawning grounds $\left(>25^{\circ} \mathrm{C}\right)$ in the Gulf of Mexico, their $k$ rapidly increase, possibly as a result of changes in vasodilation, cardiac output, and/or blood flow to the gills (Teo et al. 2007a, Graham \& Dickson 2001, 2004). It is important to note that despite the ability of a PBF to elevate its $T_{\mathrm{b}}$, its heart operates at or near $T_{\mathrm{a}}$. Blank (2004) conducted laboratory experiments on juvenile PBF and reported that prolonged exposure to waters over $30^{\circ} \mathrm{C}$ could result in cardiac failure, especially when combined with the high activity levels associated with spawning.

The physiological effects of high SSTs experienced in the spawning grounds may be compounded by the kinetically demanding nature of PBF spawning activity. Based on a video from sea-cage aquaculture environments and personal communications, PBF spawning activity is associated with elevated swimming speeds as males aggressively pursue female mates (Gen 2015). Furthermore, relatively high mortality rates have been documented for Atlantic bluefin tuna caught during scientific longline surveys in the Gulf of Mexico, and it is plausible that the energetic demand of capture (in tandem with prolonged exposure to high SSTs) results in cardiac failure for these animals (Teo et al. 2007a).

In addition, an increased $T_{\mathrm{b}}$ is one of the potential effects of feeding and digestion. We constructed a heat budget model to calculate internal heat production and $k$ using all the $T_{\mathrm{b}}$ data, including that obtained during feeding events. The estimated $k$ during the summer was higher in the night-time than in the daytime (Fig. 8). PBF are visual, opportunistic predators, and most feeding activity occurs in the daytime (e.g. Kitagawa et al. 2004). Previous studies in PBF of specific dynamic action (elevation in metabolic activity associated with the ingestion, digestion, absorption, and assimilation of a meal) have shown that it takes several hours for the metabolic rate or $T_{\mathrm{b}}$ to reach its peak and that $T_{\mathrm{b}}$ remains elevated for 20-33 h after a meal (e.g. sardine Sardinops sagax) (Whitlock et al. 2013). Therefore, post-feeding heat production may extend into the night-time, and it is possible that $k$ is actively adjusted to dissipate body 
heat. Our results clearly imply that adult PBF are able to physiologically regulate their body temperatures in the warm surface layer at night. However, further research is needed to understand the complex physiological mechanisms of PBF and how these responses can be used to detect thermal signatures of spawning activity in this species.

The combined laboratory- and field-based evidence suggests that spawning-age PBF incur increased energetic demands and an increased risk of cardiac arrest in the warm spawning grounds. Adult PBF are clearly highly migratory and are more than capable of avoiding high-temperature water masses. Nonetheless, they appear to strike an ecologyreproduction compromise when they select oceanographic conditions that promote larval success. The results presented herein revealed the behavioural adaptations exhibited by PBF exhibit to survive warm evenings in the Sea of Japan spawning grounds: they remained deep in colder waters during the daytime and periodically dove to cooler waters below the surface layer at night.

In conclusion, we found that adult PBF utilized a wide horizontal range throughout the Sea of Japan. We were fortunate to document one tagged PBF (ID252) that migrated to the known spawning grounds during the suitable spawning period. This individual exhibited a clear diel pattern in vertical distribution, likely representing a behavioural thermoregulatory strategy to gain access to optimal spawning conditions. Further research is needed that draws upon a large number of fine-scale tag records to establish a more comprehensive biological and environmental survey of PBF spawning in the Sea of Japan. Such data will help to determine the breadth of the physiology-reproduction trade-off suggested by our archival tag data for adult PBF and potential ecological considerations (i.e. broad shifts in ocean circulation and SSTs). Such information will contribute to quantitative evaluations of the reproductive potential of $\mathrm{PBF}$, facilitating improved management of this species.

Acknowledgements. We are grateful to Hidetada Kiyofuji, Yoshinori Aoki, Hiroshige Tanaka, Yosuke Tanaka, Yukio Takeuchi, Hiroshi Ashida, Hidetoshi Takashi, and Koichi Gen (National Research Institute of Far Seas Fisheries and Seikai National Research Institute, Fisheries Research Agency of Japan), Yasushi Mitsunaga (Kindai University), and other members of the university for their assistance in the tagging study. We also thank the Uchikaifu Fisherman's Association for their assistance in the field. This research was made possible by a grant from the Japan Fisheries Agency and with generous support from the Monterey Bay Aquarium.

\section{LITERATURE CITED}

Abe O, Masujima M, Suzuki N, Morimoto $\mathrm{H}$ and others (2014) Current status of spawning grounds and periods of Pacific bluefin tuna. In: International Scientific Committee for Tuna and Tuna-like Species in the North Pacific Ocean. The Informational Documents 19, Japan Information Papers, p 26-35. http://isc.fra.go.jp/pdf/ISC 14/ISC-14-Plenary-INFO-19_JPN_PBF_papers.pdf

Ashida H, Suzuki N, Tanabe T, Suzuki N, Aonuma Y (2015) Reproductive condition, batch fecundity, and spawning fraction of large Pacific bluefin tuna Thunnus orientalis landed at Ishigaki Island, Okinawa, Japan. Environ Biol Fishes 98:1173-1183

*Bakun A (2013) Ocean eddies, predator pits and bluefin tuna: implications of an inferred 'low risk-limited payoff' reproductive scheme of a (former) archetypical top predator. Fish Fish 14:424-438

Blank JM (2004) In situ cardiac performance of Pacific bluefin tuna hearts in response to acute temperature change. J Exp Biol 207:881-890

Blank JM, Morrissette JM, Farwell CJ, Price M, Schallert RJ, Block BA (2007) Temperature effects on metabolic rate of juvenile Pacific bluefin tuna Thunnus orientalis. J Exp Biol 210:4254-4261

Block BA, Jonsen ID, Jorgensen SJ, Winship AJ and others (2011) Tracking apex marine predator movements in a dynamic ocean. Nature 475:86-90

Boustany AM, Matteson R, Castleton M, Farwell C, Block BA (2010) Movements of Pacific bluefin tuna (Thunnus orientalis) in the eastern North Pacific revealed with archival tags. Prog Oceanogr 86:94-104

*Baun CD, Galuardi B, Thorrold SR (2018) HMMoce: an R package for improved geolocation of archival-tagged fishes using a hidden Markov method. Methods Ecol Evol 9:1212-1220

* Carey FG, Teal JM, Kanwisher JW, Lawson KD (1971) Warm-bodied fish. Am Zool 11:137-143

* Chen KS, Crone P, Hsu CC (2006) Reproductive biology of female Pacific bluefin tuna Thunnus orientalis from south-western North Pacific Ocean. Fish Sci 72:985-994

Fujioka K, Masujima M, Boustany AM, Kitagawa T (2015) Horizontal movements of Pacific bluefin tuna. In: Kitagawa T, Kimura S (eds) Biology and ecology of bluefin tuna. CRC Press, Boca Raton, FL, p 101-122

Fujioka K, Fukuda H, Furukawa S, Tei Y, Okamoto S, Ohshimo S (2018a) Habitat use and movement patterns of small (age-0) juvenile Pacific bluefin tuna (Thunnus orientalis) relative to the Kuroshio. Fish Oceanogr 27: 185-198

Fujioka K, Fukuda H, Tei Y, Okamoto S and others (2018b) Spatial and temporal variability in the trans-Pacific migration of Pacific bluefin tuna (Thunnus orientalis) revealed by archival tags. Prog Oceanogr 162:52-65

*Furukawa S, Tsuda Y, Nishihara GN, Fujioka K and others (2014) Vertical movements of Pacific bluefin tuna (Thunnus orientalis) and dolphinfish (Coryphaena hippurus) relative to the thermocline in the northern East China Sea. Fish Res 149:86-91

Furukawa S, Fujioka K, Fukuda H, Suzuki N, Tei Y, Ohshimo S (2017) Archival tagging reveals swimming depth and ambient and peritoneal cavity temperature in age-0 Pacific bluefin tuna, Thunnus orientalis, off the southern coast of Japan. Environ Biol Fishes 100: $35-48$ 
Galuardi B, Royer F, Golet W, Logan J, Neilson J, Lutcavage M (2010) Complex migration routes of Atlantic bluefin tuna (Thunnus thynnus) question current population structure paradigm. Can J Fish Aquat Sci 67:966-976

Gen K (2015) Physiology of bluefin tuna reproduction: new insights into reproduction in wild and captive bluefin tuna species. In: Kitagawa T, Kimura S (eds) Biology and ecology of bluefin tuna. CRC Press, Boca Raton, FL, p 325-355

Graham JB, Dickson K (2001) Anatomical and physiological specializations for endothermy. In: Block BA, Stevens ED (eds) Tuna: physiology, ecology, and evolution. Academic Press, San Diego, CA, p 121-165

Graham JB, Dickson K (2004) Tuna comparative physiology. J Exp Biol 207:4015-4024

Holland KN, Brill RW, Chang RKC, Sibert JR, Fournier DA (1992) Physiological and behavioural thermoregulation in bigeye tuna (Thunnus obesus). Nature 358:410-412

Itoh T, Tsuji S, Nitta A (2003) Swimming depth, ambient water temperature preference, and feeding frequency of young Pacific bluefin tuna (Thunnus orientalis) determined with archival tags. Fish Bull 101:535-544

Kara AB, Rochford PA, Hurlburt HE (2000) An optimal definition for ocean mixed layer depth. J Geophys Res 105: 16803-16821

Kitagawa Y, Nishikawa Y, Kubota T, Okiyama M (1995) Distribution of ichthyoplankton in the Japan Sea during summer, 1984, with special reference to Scombroid fishes. Bull Jpn Soc Fish Oceanogr 59:107-114 (in Japanese with English Abstract)

Kitagawa T, Nakata H, Kimura S, Itoh T, Tsuji S, Nitta A (2000) Effect of ambient temperature on the vertical distribution and movement of Pacific bluefin tuna Thunnus thynnus orientalis. Mar Ecol Prog Ser 206: 251-260

Kitagawa T, Kimura S, Nakata H, Yamada H (2004) Diving behavior of immature, feeding Pacific bluefin tuna (Thunnus thynnus orientalis) in relation to season and area: the East China Sea and the Kuroshio-Oyashio transition region. Fish Oceanogr 13:161-180

Kitagawa T, Kimura S, Nakata H, Yamada H (2006a) Thermal adaptation of Pacific bluefin tuna Thunnus orientalis to temperate waters. Fish Sci 72:149-156

Kitagawa T, Sartimbul A, Nakata H, Kimura S, Yamada H, Nitta A (2006b) The effect of water temperature on habitat use of young Pacific bluefin tuna Thunnus orientalis in the East China Sea. Fish Sci 72:1166-1176

Kitagawa T, Kato Y, Miller MJ, Sasai Y, Sasaki H, Kimura S (2010) The restricted spawning area and season of Pacific bluefin tuna facilitate use of nursery areas: a modeling approach to larval and juvenile dispersal processes. J Exp Mar Biol Ecol 393:23-31

Kodama T, Hirai J, Tamura S, Takahashi T and others (2017) Diet composition and feeding habits of larval Pacific bluefin tuna Thunnus orientalis in the Sea of Japan: integrated morphological and metagenetic analysis. Mar Ecol Prog Ser 583:211-226

Lam CH, Nielsen A, Sibert JR (2008) Improving light and temperature based geolocation by unscented Kalman filtering. Fish Res 91:15-25

Masuma S (2006) Maturation and spawning of bluefin tuna in captivity. In: Sakamoto W, Miyashita S, Nakagawa Y (eds) Proc Kinki University Int Symp on ecology and aquaculture of bluefin tuna. Kinki University Press, Amami Oshima, p 15-19
Miyashita S, Tanaka Y, Sawada Y, Murata O and others (2000) Embryonic development and effects of water temperature on hatching of the bluefin tuna, Thunnus thynnus. Suisan Zoshoku 48:199-207 (in Japanese with English Abstract)

Muhling BA, Reglero P, Ciannelli L, Alvarez-Berastegui D, Alemany F, Lamkin JT, Roffer MA (2013) Comparison between environmental characteristics of larval bluefin tuna Thunnus thynnus habitat in the Gulf of Mexico and western Mediterranean Sea. Mar Ecol Prog Ser 486: 257-276

* Nielsen A, Bigelow KA, Musyl MK, Sibert JR (2006) Improving light-based geolocation by including sea surface temperature. Fish Oceanogr 15:314-325

* Ohshimo S, Tawa A, Ota T, Nishimoto S and others (2017) Horizontal distribution and habitat of Pacific bluefin tuna, Thunnus orientalis, larvae in the waters around Japan. Bull Mar Sci 93:769-787

* Ohshimo S, Sato T, Okochi Y, Ishihara Y and others (2018) Long-term change in reproductive condition and evaluation of maternal effects in Pacific bluefin tuna, Thunnus orientalis, in the Sea of Japan. Fish Res 204:390-401

* Okochi Y, Abe O, Tanaka S, Ishihara Y, Shimizu A (2016) Reproductive biology of female Pacific bluefin tuna, Thunnus orientalis, in the Sea of Japan. Fish Res 174: 30-39

Schaefer KM (1998) Reproductive biology of yellowfin tuna (Thunnus albacares) in the eastern Pacific Ocean. Bull IATTC 21:201-272

Schaefer KM (2001) Reproductive biology of tunas. In: Block BA, Stevens ED (eds) Tuna: physiology, ecology, and evolution. Academic Press, San Diego, CA, p 225-270

* Schaefer KM, Fuller DW, Block BA (2011) Movements, behavior, and habitat utilization of yellowfin tuna (Thunnus albacares) in the Pacific Ocean off Baja California, Mexico, determined from archival tag data analyses, including unscented Kalman filtering. Fish Res 112: 22-37

Shimose T, Tanabe T, Chen KS, Hsu CC (2009) Age determination and growth of Pacific bluefin tuna, Thunnus orientalis, off Japan and Taiwan. Fish Res 100: 134-139

* Shimose T, Aonuma Y, Tanabe T, Suzuki N, Kanaiwa M (2018) Solar and lunar influences on the spawning activity of Pacific bluefin tuna (Thunnus orientalis) in the south-western North Pacific spawning ground. Fish Oceanogr 27:76-84

* Stevens ED, Lam HM, Kendall J (1974) Vascular anatomy of the counter-current heat exchanger of skipjack tuna. J Exp Biol 61:145-153

Tanaka M, Kaji T, Nakamura Y, Takahashi Y (1996) Developmental strategy of scombrid larvae: high growth potential related to food habits and precocious digestive system development. In: Watanabe Y, Yamashita Y, Oozeki Y (eds) Survival strategies in early life stages of marine resources. AA Balkema, Rotterdam, p 125-139

* Tanaka Y, Satoh K, Iwahashi M, Yamada H (2006) Growthdependent recruitment of Pacific bluefin tuna Thunnus orientalis in the northwestern Pacific Ocean. Mar Ecol Prog Ser 319:225-235

Tanaka Y, Mohri M, Yamada H (2007) Distribution, growth and hatch date of juvenile Pacific bluefin tuna Thunnus 
orientalis in the coastal area of the Sea of Japan. Fish Sci 73:534-542

Tawa A, Ishihara T, Uematsu Y, Ono T, Ohshimo S (2017) Evidence of westward transoceanic migration of Pacific bluefin tuna in the Sea of Japan based on stable isotope analysis. Mar Biol 164:94

Teo SLH, Boustany A, Dewar H, Stokesbury MJW and others (2007a) Annual migrations, diving behavior, and thermal biology of Atlantic bluefin tuna, Thunnus thynnus, on their Gulf of Mexico breeding grounds. Mar Biol 151:1-18

Teo SLH, Boustany A, Block BA (2007b) Oceanographic preferences of Atlantic bluefin tuna, Thunnus thynnus, on their Gulf of Mexico breeding grounds. Mar Biol 152: 1105-1119

Uda M (1957) A consideration on the long years trend of the fisheries fluctuation in relation to sea condition. Bull Jpn Soc Sci Fish 23:368-372

Whitlock RE, Walli A, Cermeno P, Rodriguez LE, Farwell C, Block BA (2013) Quantifying energy intake in Pacific bluefin tuna (Thunnus orientalis) using the heat increment of feeding. J Exp Biol 216:4109-4123

Yamada H, Yano K, Takeharu K (2004) The pop-up archival satellite tag revealing the tuna migration. J Adv Mar Sci Technol Soc 9:201-207 (in Japanese with English Abstract)

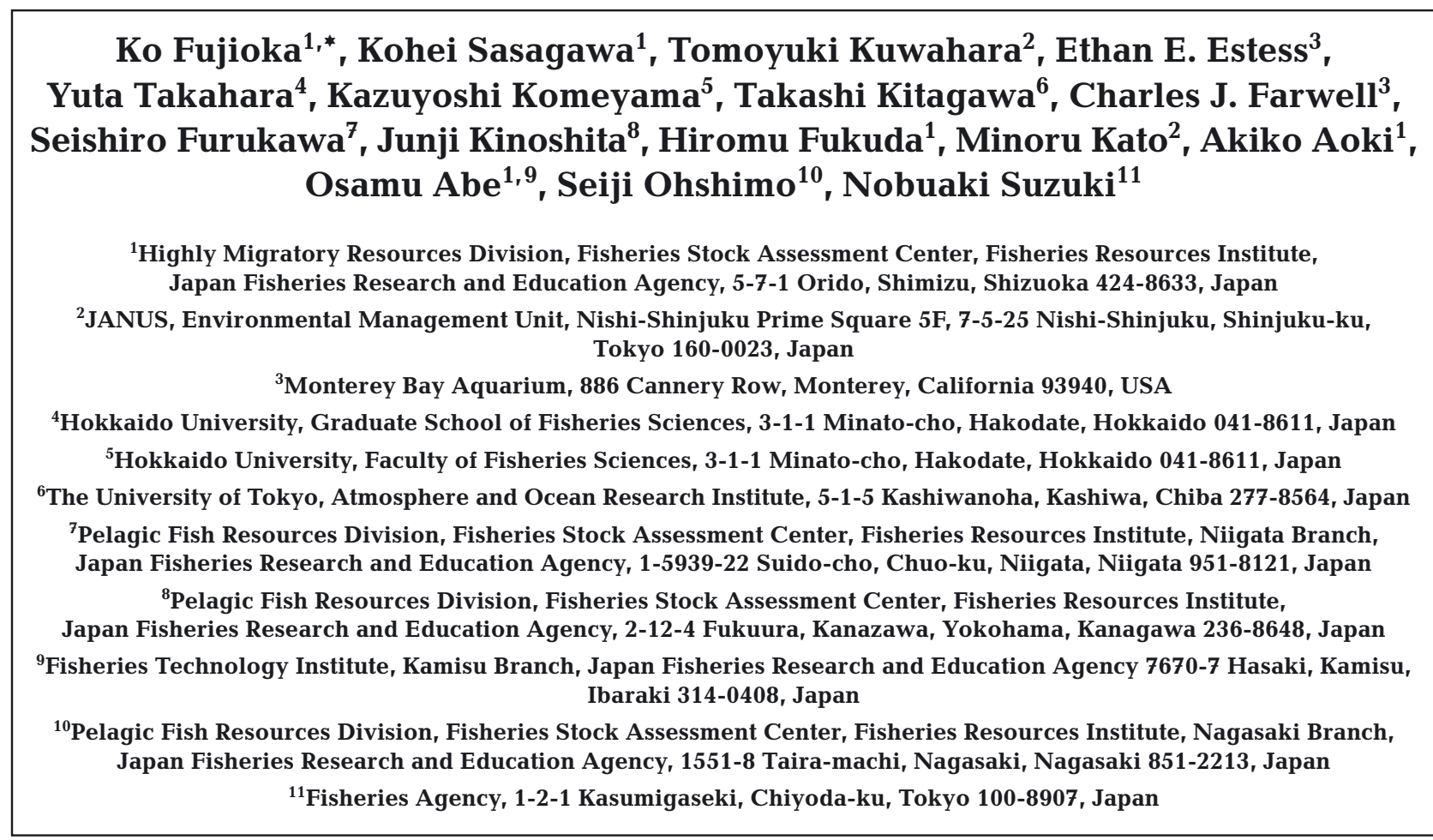

Editorial responsibility: Alistair Hobday, Hobart, Tasmania, Australia

Reviewed by: $S$. Teo and 1 anonymous referee
Submitted: August 14, 2020

Accepted: May 3, 2021

Proofs received from author(s): June 20, 2021 